Northwestern University School of Law Northwestern University School of Law Scholarly Commons

Faculty Working Papers

2010

\title{
Whales: Their Emerging Right to Life
}

Anthony D'Amato

Northwestern University School of Law, a-damato@law.northwestern.edu

Sudhir K. Chopra

Cambridge University East Asia Forum

\section{Repository Citation}

D'Amato, Anthony and Chopra, Sudhir K., "Whales: Their Emerging Right to Life" (2010). Faculty Working Papers. Paper 63.

http://scholarlycommons.law.northwestern.edu/facultyworkingpapers/63

This Article is brought to you for free and open access by Northwestern University School of Law Scholarly Commons. It has been accepted for inclusion in Faculty Working Papers by an authorized administrator of Northwestern University School of Law Scholarly Commons. 


\title{
Whales: Their Emerging Right to Life, by Anthony D'Amato and Sudhir K. Chopra* \\ 85 American Journal of International Law 21-62, Jan 1991
}

\begin{abstract}
We have contended in this article that the evolution of the opinio juris of nations has encompassed five, and perhaps six, inexorable qualitative stages: free resource, regulation, conservation, protection, preservation and entitlement. We have argued that assigning whales an entitlement to life is the consequence of an emerging humanist right in international law - an example of the merging of the "is" and the "ought" of the law in the process of legitimization Tags: Whales and whaling, whaling moratorium, regulation of whaling, International Whaling Commission
\end{abstract}

[pg21] **Writers of science fiction have often speculated about what it would be like to discover, on a planet in outer space, a much higher form of intelligence. How would we react to those creatures? Would we be so fearful of them that we would try to kill them? Or would we welcome the opportunity to attempt to understand their language and culture?FN1 Stranger than fiction is the fact that there already exists a species of animal life on earth that scientists speculate has higher than human intelligence. The whale has a brain that in some instances is six times bigger than the human brain and its neocortex is more convoluted.FN2 Discussing the creative processes of whales, Dr. John Lilly says that a researcher "is struck with the fact that one's current basic assumptions and even one's current expectations determine, within certain limits, the results attained with a particular animal at that particular time."FN3 Whales speak to other whales in a language that appears to include abstruse mathematical poetry.FN4 They have also developed interspecies communication with dolphins.FN5 Whales are the most specialized of all mammals.FN6 [pg22] They are sentient, they are intelligent, they have their own community, and they can suffer. Yet because they have no hands to fashion tools or construct weapons for self-defense- because they "do not have the ability to drive harpoons through living flesh"FN7-they are vulnerable to human predation.FN8 Many species of whales have been savagely hunted to near extinction. Even today, despite the international restrictions that have made the outfitting of new whaling vessels unprofitable, whalers already in the business-using their sunk capital investments - continue to search out and destroy these magnificent creatures.FN9

Professor Richard Falk writes that "it is a late hour on the biological clock that controls cetacean destiny, but hopefully not too late."FN10 Australia, a nation that in years past had engaged heavily in whaling, declared in 1979 that "the harpooning of these animals is offensive to many people who regard killing these special and intelligent animals as inconsistent with the ideals of mankind, and without any valid economic purpose in mitigation."FN11 Yet national policies do not automatically transmute into international legal restrictions.FN12 Neither the present opposition to whaling of an overwhelming number of states nor the ethical revulsion of many people throughout the world protects whales from the whale-hunting minority of states or gives them an international legal entitlement to survive. Even if some observers feel that the burgeoning international law of "human rights" should in principle include the preservation of whales, that very label seems inappropriate because it connotes species chauvinism.FN13

This essay examines the history, and argues for the "presentiation,"FN14 of a broadening international consciousness about whaling amounting to an opinio juris - the psychological component of international customary law. When this component is added to the evolving practices of states toward whaling, the combination [pg23] of psychological and material elements arguably constitutes binding customary law.FN15 The dynamic element of that custom and its underlying philoso- 
phy generate, we conclude, an emergent entitlement of whales — not just "on behalf of" whales — to a life of their own.FN16

We begin in part I with an inferred moral claim of whales to live and to be left alone. Next, in part II, we present an analytical history of the policies and practices of the various international institutions concerned with whaling. We attempt to show that over time their policies have generally moved through five analytic stages-free resource, regulation, conservation, protection and preservation — and perhaps into a sixth, entitlement. We contend that this sixth stage is either an actuality or at least an actualizable development entailed by the preceding five stages. In part III we analyze the entitlement stage, showing the difference it can make in respect of legal initiatives. Part IV is devoted to the two current counterclaims on behalf of whaling: the "scientific research" claim and the "aboriginal" claim. We end our presentation with a brief conclusion.

\section{THE MORAL CLAIM}

A weak claim of environmental awareness is that we must concern ourselves with the integrity of the environment because of a duty to future generations. The asserted "duty to future generations" is subject to Parfit's demonstration that it is self-defeating.FN17 We may then choose to move to a stronger claim of environmental awareness - that we owe a duty to living creatures in the environment per se, without calculating their utility to future generations of human beings. The dawning of such a sense of duty involves a broadening of humanistic consciousness comparable to the Copernican revolution that changed the Ptolemaic earth-centered conception of the universe to the modern realization that ours is but a minor planet revolving around a minor star in only one of billions of galaxies. We may be at the brink of replacing the view that "nature" exists only to serve people, with a larger ecological awareness that people share and ought to share the planet with many other sentient creatures.

This strong environmental claim requires at a minimum that we pause to consider the effect of certain human activities upon other living creatures. The story of the harpooning of a whale FN18 is illustrative in this regard:

The first observation was logged at 12:15 when the whale, a bull sperm of nearly 50 feet, surfaced near the canoa,FN19 with a launch in fast pursuit, the harpooner on the bow throwing a lance just as the whale sounded. Apparently the master already realized that they had an unusually wary and resourceful whale on their harpoon.

[pg24] Lances are thrown repeatedly into the whale.

[T]he brave bull whale, through the day lanced again and again, dives and eludes, dragging the whalers after him. Never once does he attempt to attack his hunters. An impossible ten hours later, the light is fading and the launch driver is for cutting the line and letting the whale loose, but the master, who is known for his tenacity, determines to hold the whale through the night.

No lancing is attempted during the night. The whalers work the harpoon line, always trying to maintain tension, forcing the whale to dive as quickly as possible, and always trying to herd it toward a nearby island. Then at dawn: 
[The whale] surfaces, spouting every 10 to 13 seconds. The harpooner goes into the canoa, and the canoa creeps up behind the whale, slowly, hand over hand. The canoa rows the last 50 yards. The whale is swimming very slowly. The harpooner throws the lance repeatedly, in the end using the lance to jab deeply without throwing. Twenty-one thrusts are made, and the whale begins spouting fountains of blood. . . .

7:42 — The whale is spouting every 10 to 13 seconds, some spouts are almost clear, others seem almost pure blood fountains. ...

7:46 - The whale surfaces, seems tired, confused, hurt. The harpooner thrusts his lance 18 times more, the canoa stays close.

8:00 - Still lancing.

8:07 - Still lancing, there is no point in counting. The harpooner is working close enough to jab the lance deeply, over and over. ...

8:20 - Thirty seconds between spouts, heavy blood. . . .

8:41 - Twenty seconds between spouts, whale upright, canoa waits nearby for the death which must come soon.

9:00 — Heavy spout of blood, the whale rolls slightly, tail showing. . . .

9:15 - Shows right flipper in a dizzy slow motion roll, one fluke emerges.

9:36 - Tail showing constantly, the whale lying partially on his side. . .

9:55 - The whale is dead.

The whale has taken 23 hours and 40 minutes to die.FN20

Jeremy Bentham, the founder of legal positivism, wrote in 1789 of the moral status of animals: "The question is not, Can they reason? nor Can they talk? but, Can they suffer?"FN21 When whales are harpooned and dying, their characteristic [pg25] whistles change dramatically to a low monotone. In contrast, in the normal healthy state, their whistles "are beautiful bird-like sounds with trills and arpeggios, glissandos and sitar-like bends in the notes."FN22 This change is clearly analogous to the transformation in human expression from talking (or singing) in the normal state to crying when in pain. Additionally, there can be little physiological doubt that whales feel pain; indeed, the real question is whether they perceive acute pain to an even greater degree than humans. This latter possibility is evidenced by the far wider range of skin sensations apparently registered by the complex cerebral cortex of the whale.FN23

Anyone who has watched a mammal in intense pain — a dog, a cat, a rabbit, a horse-knows that the animal is suffering and, moreover, that it is aware of its own suffering.FN24 When we consider whales, whose intelligence may be superior to our own,FN25 it is nearly impossible to avoid concluding that these majestic creatures are capable of a degree of suffering that we may not be able to fathom.

Yet there is a philosophical tradition going back to Descartes that holds that animals other than humans lack the necessary thought processes for awareness of their own suffering and pain. Noam Chomsky quotes a letter from Descartes of 1647 to Henry More: 
But the principal argument, to my mind, which may convince us that the brutes are devoid of reason, is that, . . . it has never yet been observed that any animal has arrived at such a degree of perfection as to make use of a true language; that is to say, as to be able to indicate to us by the voice, or by other signs, anything which could be referred to thought alone, rather than to a movement of mere nature; for the word is the sole sign and the only certain mark of the presence of thought hidden and wrapped up in the body; now all men, the most stupid and the most foolish, those even who are deprived of the organs of speech, make use of signs, whereas the brutes never do anything of the kind; which may be taken for the true distinction between man and brute.FN26

Fontenelle, a contemporary of Descartes, wrote:

They [the scientists] administered beatings to dogs with perfect indifference, and made fun of those who pitied the creatures as if they had felt pain. They said that the animals were clocks; that the cries they emitted when struck, were only the noise of a little spring which had been touched, but that the whole body was without feeling. They nailed poor animals up on boards by their four paws to vivisect them and see the circulation of the blood. . . FN27

[pg26] Philosophically, the Cartesian thesis is unpersuasive for two complementary reasons. The first is that it is overinclusive. Philosophers such as Wittgenstein have pointed out that the only basis we have for assuming that even another human being can feel pain is the other's distinctive bodily movements, sounds and cries.FN28 We have no guarantee that another person feels "pain" the way we do and, moreover, we are not ourselves sure that by labeling an internal condition "painful" we are able to convey what we internally experience to others.FN29 Thus, when a Cartesian philosopher argues that we do not know whether a wounded dog or whale feels pain, similar reasons apply to whether a wounded person feels pain. Descartes's skepticism is therefore overinclusive.

Second, the Cartesian thesis is underinclusive. In the letter quoted above, Descartes says that animals lack the ability to "indicate to us" their thoughts. But why should animals have evolved an ability to indicate anything to human beings? Is it not enough that they may be able to communicate adequately with their own species? Whales evolved their large brains 30 million years ago 25 million years before humans appeared on the scene and 29 million years before the present brain size of humans developed.FN30

Why should whales have evolved with a capacity to communicate their ideas to homo sapiens when the latter appeared only at the very end of the 30 million years of the whale's history? There is overwhelming evidence that whales communicate effectively with their own species (and, as previously noted, have even developed interspecies communication).FN31 The notion that animals do not think because they have not learned to talk with us is arbitrarily underinclusive. Our failure to converse with whales could well be a matter more of our own limitation than of theirs.

Thus, a combination of overinclusiveness and underinclusiveness renders the Cartesian thesis arbitrary and unpersuasive. Throughout history, the denial that other persons—outsiders, minority groups - as well as other animals, have a consciousness equivalent to our own has been the foundational philosophy for genocide and enslavement. This kind of denial of humanity to minority groups is the clearest form of inhumanity. The base evil of genocide, torture, or enslavement of minority or defenseless groups is matched only by the pseudo-rationalization that the victims are less than human. Charles Darwin saw clearly the empathic connection between opposition to slavery and opposition to cruelty to animals. According to his son, "The two subjects which moved my fa- 
ther perhaps more strongly than any others were cruelty to animals and slavery. His detestation of both was intense, [pg27] and his indignation was overpowering in case of any levity or want of feeling on these matters."FN32

Those who would deny whales the right to live use a similar rationalization. To be sure, whales are not human, but are they "less" than human? The mind set that exults in the killing of whales and the "sports" hunting of endangered wildlife species overlaps with the mind set that accepts genocide of "inferior" human being. Conversely, the extension of rights to whales resonates deeply with the historical-legal extensions of equal rights to women and to minority groups. We believe that the phrase "human rights" is only superficially species chauvinistic.FN33 In a profound sense, whales and some other sentient mammals are entitled to human rights or at least to humanist rights - to the most fundamental entitlements that we regard as part of the humanitarian tradition. They are entitled to those fundamental rights not because they re "less" than human but because they are "different" from humans in various respects that do not affect or qualify the rights in question. In this article we argue only for extending the single most fundamental of all human rights - the right to lifeto whales.FN34

Finally, let us consider a philosophically intermediate position between according rights to whales and abusing them. One might contend that so long as whales are not intentionally maltreated, there is no need to consider them as rights holders. This position is an echo of David Hume's speculation that creatures otherwise like us but lacking the power to harm us can at most hope to be treated mercifully but cannot expect to be treated justly.FN35 But, as Allen Buchanan points out, such a position would also deny rights to persons who are unable to contribute to society, such as those who from birth are severely and permanently incapacitated.FN36 Our moral obligations to others cannot be grounded on our expectation of future help from them. Even so, we cannot now know what potential future benefit to persons the continued existence of whales might afford. Medical sciences is replete with examples of cures derived from animals and plants, many of which seemed useless and some of which were at the point of extinction when the therapeutic [pg28] discovery was made. Yet morality cannot be a matter of self-interested or prudential calculation, but is rather a deontological obligation that we owe to others even at the possibility of a net cost to ourselves.FN37 Unless we acknowledge that sentient creatures such as whales are rights holders-even if those rights are limited to a few fundamental ones-we open the door to acknowledging the propriety of a future technological development that would assure the "painless" mass slaughter of whales, arguably without mistreating or abusing them. The philosophically intermediate position, on analysis, is inconsistent with our moral tradition.

\section{THE INTERNATIONAL LAW CLAIM}

The entitlement of whales to live and be left alone has arguably resulted from the developing practices of various institutions - international, conventional and national-concerned with whaling.

We have already mentioned our contention that these practices may be organized into six historical-analytical stages, and that a proper evaluation of the first five argues powerfully for the emergency of the sixth - entitlement of whales to life. Our discussion of these stages employs purposive as well as descriptive materials, because customary international law itself is a synthesis of quantitative and qualitative elements.FN38 


\section{The Free Resource Stage: Up to World War I}

For centuries, whales were considered a free resource, a gift from nature available to anyone who would hunt and kill them. Through the centuries, unregulated whaling caused the depletion of many species.FN9 Industrial whale hunting began with the Basques in the Bay of Biscay in the eleventh century FN40 and rapidly developed into a commercial industry that provided lamp oil and whalebones in response to the fashion of time.

By 1578, Basque vessels had extended their activity to Newfoundland in the North Atlantic. The British and Dutch followed soon thereafter and so expanded their activity that Basque whaling nearly ceased by the end of the sixteenth century. Increased whaling activities led to the near extinction of right whalesFN41 from [pg29] the North Atlantic a century later.FN42 While the Dutch industry then declined, British whalers continued their activity throughout the nineteenth century around Biscaya and Greenland. French and German whalers joined the hunt, causing the near extinction of Greenland bowhead whales FN43 and Biscayan right whales.FN44

American whalers entered the industry in the eighteenth and nineteenth centuries. On the East Coast, whaling took place off Massachusetts, Connecticut, and New York. In the West, gray and right whales were hunted off the California coast. After depleting the stocks in coastal waters, American whalers moved on to South American, Australia and New Zealand.FN45 According to some accounts, by the mid-nineteenth century over seven hundred American vessels and seventy thousand people were employed in the industry.FN46 American whaling slowed down during the Civil War and after the introduction of the petroleum industry, and gradually came to an end at the beginning of the twentieth century.

At the same time that the American industry began to decline, the middle of the nineteenth century, the biggest of all the Antarctic and Arctic whaling periods was launched. Advances in technology overcame distance as a prohibitive factor in the pursuit of pelagic whaling. Norwegians developed more effective harpoons and equipped their ships with steam engines.FN47 To facilitate processing, land stations were established.FN48 In 1904 Norway established its first Antarctic whaling station in Georgia.FN49

The Norwegian lead in technology was soon followed by many other nations.FN50 In the twentieth century, the commercial fleets have hunted the largest whales, in particular the finbacks, humpbacks, bowheads, and sperm, blue, sei, right and gray whales. In 1910 over ten thousand whales were killed.FN51 By 1914-1915, Norway alone was responsible for killing 14,917 whales just in Antarctic waters. FN52 During the First World War the total declined to 9,468 by 19181919.FN53 However, after the war it steadily increased from 11,369 in 1919-1920 to 43,129 in 1931. FN54 Finally, whaling nations perceived - entirely in their own self-interest - that some form of regulation was needed.FN55

\section{[pg30] The Regulation Stage: 1918-1931}

Even before fears arise of the extinction of a species, the hunting and fishing industries realize that their collective profits depend upon the availability of sizable numbers of that species. For example, if there are only a few whales in the Indian Ocean, the time that any whaling vessel has to spend in finding and capturing a whale will be increased perhaps to the point of making the venture unprofitable. Hence, we might expect the whaling industry to agree to setting up a licensing system 
imposing temporal and spatial restrictions upon its activities. During the period roughly from 1918 through 1931, there was limited international regulation of the whaling industry for these purposes.

The most important effort was made at the meeting of the Whaling Committee of the International Council for the Exploration of the Sea held in 1927. At this meeting the Norwegian delegate proposed that whaling countries prohibit the further expansion of whaling and institute a licensing system. On the recommendation of the Whaling Committee, the International Bureau of Whaling Statistics was established in 1930;FN56 after further negotiations the Convention for the Regulation of Whaling was concluded in 1931 FN57 Five years later, this Convention came into force under the auspices of the League of Nations. FN58

The 1931 Convention for the first time set forth whaling regulations covering all waters,FN59 including territorial waters within national jurisdiction.FN60 Contracting parties undertook to take appropriate measures to license their vessels.FN61 Salaries of gunners and crew were required to be based on the size and species of the whale and the value and yield of the oil.

\section{The Conservation Stage: 1931-1945}

The 1931 Convention went beyond mere regulation for the purpose of maintaining abundant harvest. Certain measures of actual conservation were introduced. "Conservation" as we use the term implies taking a long-term view of the health of an industry. It looks beyond immediate economic considerations relating to profit and efficiency, and introduces the notion of longevity for the industry. But, like regulation, it is still aimed at the health of the whaling industry and not all the health of whales.

[pg31] Along these lines, the 1931 Convention prohibited the taking or killing of calves, immature whales and female whales accompanied by calves.FN62 More significantly, the taking of right whales and several other species was flatly prohibited.FN63 While the latter prohibitions might be construed as an incipient recognition of a duty not to extinguish a species, from the standpoint of the 1930s this interpretation is probably unjustified. Rather, the flat prohibition on the taking of right whales, for example, was more likely a conservation measure that would be removed in a future convention as soon as right whales became more abundant. All told, despite the theoretical advance toward conservation marked by the 1931 Convention, it was largely ineffective in reducing the overexploitation of whales.FN64

A development of a different nature in the early 1930s had a more substantial effect upon the industry. The 1930-1931 catch produced a prodigious 3.6 million barrels of whale oil, an oversupply that led to a precipitous decline in the market. To control the falling prices of whale oil, the private companies negotiated agreements to restrict and reduce their catch. While these measures were purely economic, they proved to be of great help in conserving whale stocks in the 1930s.FN65 However, the agreements between 1932 and 1936 were temporary and, in any event, were not acceptable to Japan, Germany and the Soviet Union.FN66

Another conference was held in 1937,FN67 leading to the conclusion of the International Agreement for the Regulation of Whaling.FN68 This Agreement was a marked improvement over the 1931 Convention. Under the Agreement, the taking of both gray whales and right whales was prohibited.FN69 Included were limitations on hunting areas and the length of the whaling season. For each species of whales, a minimum season was established, which offered at least formal protection for young and immature whales.FN70 
In practice, however, whaling continued largely unabated. A protocol to amend the 1937 Agreement was entered into in 1938.FN71 By now, whaling operations were so "excessive that it was seriously suggested that all regulations be dropped and [pg32] indiscriminate whaling allowed until stocks were reduced to the level at which whaling ceased to be remunerative."FN72 What that suggestion overlooked was the economic fact, so evident today, that even unremunerative whaling will proceed as long as there is sunk capital in whaling vessels. For although it is uneconomic to build new vessels (because of the low expected return), it is also uneconomic not to use existing ones even when the expected return is minimal. As a result, working whalers may be expected to pursue whales to the point of total extinction. Nor would the level of whaling activity necessarily decline even if the number of whaling nations declined to one or two-for example, when Great Britain and the Netherlands opted out of whaling, Japan purchased many of their factory ships and acceded to the British and Dutch international whaling quotas as well.FN73 Moreover, the increasing scarcity of whales may drive up the prices of whale products, perversely stimulating those whalers to pursue whales to extinction.

The extermination of the entire whale species surfaces as a major concern by 1938.FN74 The 1938 Protocol banned the taking of humpback whales for two years except in the area south of 40 degrees south latitude, where a one-year ban was imposed.FN75 A year later, modifications to the Protocol were adopted that provided minor additional protection for the humpback whale.FN76 On the whole, however, the agreements of the 1930s failed to achieve their stated objectives. Professor Birnie sums up the reasons for this failure: "inadequacy of the scope of regulations; inadequate scientific data; non-cooperation by some major whaling nations; poor enforcement of agreements and no international supervision or control; and lack of global interest.FN77

During World War II a series of agreements were adopted, the most important being the 1945 Protocol, which became effective in its entirety in 1947.FN78 The Protocol introduced maximum catch quotas for the total season for Antarctic pelagic whaling. Not more than sixteen thousand units of blue whales were to be taken in the open season.FN79 A formula of equating other species of whales with blue whales was developed.FN80

\section{Conservation Becomes Protection: 1945-1977}

The next historical period is characterized by an admixture of conservationist and protectionist sentiment evolving toward the protectionist end of the spectrum. It is difficult to pinpoint when conversation — undertaken for the health of the whaling industry — starts to become transformed into protective measures undertaken for the survival and longevity of whales as a species. The transition is [pg33] psychological, even though manifested in legal instruments. consider the parallel case of United States forests: originally founded for purposes of conservation (to preserve the long-term livelihood of the lumber industry), the conservation movement has transformed itself, through groups like the Sierra Club, into advocates of protecting forests as such. The change in attitude occurs a lot sooner in some people (such as Sierra Club members) than in others, which makes it nearly impossible to draw the line between an era of conservation and an era of protectionism.

In 1945 President Truman issued several proclamations that inaugurated a new era of concern for oceanic and suboceanic conservation. The most important of these proclamations, for present purposes, established the right of the United States to create conservation zones for fisheries beyond the territorial seas.FN81 this unilateral act, far from being denounced by other states, started a trend among coastal states toward the establishment of large coastal zones to protect marine resources 
that hitherto had received no protection under international norms establishing freedom of the seas.FN82

Also at the end of the Second World War, most whaling nations recognized the need for a new international convention. The United States called for a conference in late 1946. The new International Convention for the Regulation of Whaling (ICRW), superseding previous agreements, came into effect on November 10, 1948.FN83 At this time, public international law still regarded the sea as open to unregulated fishing.FN84 The ICRW reflected this simple dichotomy, even though the Truman proclamations had already taken the first step toward a new [pg34] era of flexible conservationist zones. The conservationist philosophy of the ICRW is contained in its Preamble, where the following points are made:

(1) it is in the interest of the nations of the world to safeguard for future generations the great natural resource represented by the whale stocks;

(2) that in view of the "history of whaling [which] has seen overfishing of one area after another and of one species of whale after another" to near extinction, "it is essential to protect all species of whales from further over-fishing."FN85

However, the ICRW has mixed objectives; while the Convention is intended to protect whales from overexploitation, the Preamble also states that the parties desire to "establish a system of international regulation for the whale fisheries to ensure proper and effective conservation and development of whale stocks."FN86

The ICRW established the International Whaling commission (IWC), which meets annually to adopt and revise annual quotas, and to identify protected species. We shall pay considerable attention to the developing practices of the IWC in this article.FN87

The ICRW is hardly a revolutionary document. Yet the first sign of protection of whales is found in its Preamble, which sets the ultimate purpose of the convention as "to provide for the proper conservation of whale stocks and thus make possible the orderly development of the whaling industry." Significantly, conservation is given priority over the interests of the whaling industry. The term "proper conservation" seems to be an end in itself, a byproduct of which is to make possible the orderly development of the whaling industry. Almost unobtrusively, the first sign of concern for protecting whales as such was introduced into a lawmaking treaty.

A schedule attached to the ICRW outlines methods of regulation for the IWC. The amendable regulations of the schedule fix protected and unprotected species; open and closed seasons; open and closed areas, including sanctuaries; limitations on the size of species taken; methods and intensity of whaling, including maximum catch; types of gear and equipment used; methods of measuring whales taken; the requirement that returns be made of catch; and statistical and other biological information.FN88 The critical ability to regulate quotas is found in Article V (amended in 1956).

The ability of the IWC to prescribe and regulate quotas gave the ICRW a flexibility and continuity that the previous treaties lacked. Yet the period 1948-1960 was marked by frequent clashes and threats by nations to withdraw from the Commission.FN89 Most of these early years were spent arguing over scientific data [pg35] and quota allocations pertaining to Antarctic whaling. At the seventh meeting, in 1955, Norway proposed that the IWC appoint international observers for all factory ships. This proposal was prompted by the recognition that the Convention was being poorly 
enforced.FN90 At the tenth meeting, held in 1958, the parties for the first time discussed the humaneness of the killing of whales.FN91

Despite the generally poor enforcement of the Convention, certain regional initiatives were taken to strengthen the policies of the IWC. The most prominent of these set up the Permanent Commission of the Conference on the Use and Conservation of the Maritime Resources of the South Pacific (PCSP).FN92 this conference in 1954 adopted measures to regulate the whaling and fishing activities of Chile, Ecuador and Peru inter se. Although these countries had recently declared their own 200-mile territorial seas, they did not explicitly limit the purview of the new regulations to the 200-mile zones.FN93 The South Pacific Commission was established to manage 'the marine fauna of the water," a rather comprehensive term including all marine mammals, as well as fish, although one of the primary objectives was to manage and conserve whales. The IWC regulations, except where they conflicted with "just needs for national consumption and industrial supplies."FN94 Although the latter was a large loophole, the PCSP at least placed the burden of justification upon national claimants. In the case of whales, as distinct from other marine fauna, it would prove difficult to justify whaling for either consumption or industrial purposes.FN95

Ten years after the establishment of the IWC, the 1958 Geneva Convention on Fishing and Conservation of the Living Resources of the High Seas was signed.FN96 The 1958 Geneva Conference on the Law of the Sea adopted two resolutions to strengthen the effectiveness of the international conservation organizations and to further support the use of international conservation conventions.FN97 Of particular [pg36] note is the definition of "conservation of the living resource of the high seas" in the Convention itself. Article 2 explains that the "expression 'conservation of the living resources of the high seas' means the aggregate of the measures rendering possible the optimum sustainable yield from those resources." In short, the Convention defines conservation as maximum sustainable yield (MSY). But MSY came under immediate attack by the proponents of eumetric theory, who charged that MSY pays attention only to the physical output of the whaling industry and is therefore underinclusive regarding the goal of conservation.FN98 Because MSY does not take into account the costs to fishermen, to society, and to the environment, it results in too high a figure for yield.FN99 Eumetric theory would require quotas to be set below the level of MSY. But eumetric theory was still too radical to be generally accepted in the late 1950s when the prevailing attitude was that oceanic resources were infinite.

Another significant development at the 1958 Geneva conference was the adoption of a resolution entitled "Humane Killing of Marine Life," which directly deals with whales: "The United Nations Conference on the Law of the Sea Requests States to prescribe, by all means available to them, those methods for the capture and killing of marine life, especially of whales and seals, which will spare them suffering to the greatest extent possible."FN100 This resolution reflects changing perceptions about whales outside the IWC and recognition of the principle of more humane treatment of whales and other marine life.

The 1950's closed with the conclusion of the Antarctic Treaty,FN101 which had an important impact upon perceptions about whaling. Completed in 1959, the Treaty was designed both to ensure that the Antarctic would forever be used exclusively for peaceful purposes and to promote cooperation in scientific research.FN102 [pg37] A major conservation development that grew out of the Antarctic Treaty system was the adoption in 1972 of the Convention for the Conservation of Antarctic Seals, on the recommendation of the Antarctic Treaty Consultative Party group (ATCPs). This was a momentous Convention for Antarctic marine mammals since it acknowledged the im- 
portance of the Antarctic ecosystem.FN103 Early on, the ATCPs recognized the dangers to the fragile ecosystem of Antarctica and the need to preserve it in its entirety-a matter of obvious significance for Antarctic whales.FN104 The parties to the Antarctic Treaty have instituted measures to prevent harm to the Antarctic marine environment through direct and indirect means.FN105

As the 1960s began, the mood among IWC member states was to safeguard their national economic interests; they tended to ignore the Commission's scientific advice. The only three developments of some significance were the adoption of the International Observer Scheme in 1963, the prohibition the same year on harvesting the humpback whale, and the prohibition in 1964 on catching the blue whale - both of them endangered species.FN106 But the IWC in the 1960s failed to meet its principal objective of conserving whale resources at their 1946 levels.

When the IWC was established in 1948 there were only a few fisheries commissions, but by 1960 there were twelve.FN107 From time to time, the IWC has been [pg38] influenced by these commissions and regional fisheries organizations to adopt sounder and more scientific criteria for the establishment of whaling quotas. Of the twelve fisheries commissions, only the PCSP specifically deals with whales. The PCSP is empowered to undertake biological studies on the conservation of whales and it also collaborates with the IWC.FN108 The regulatory scope of the other commissions varies. Yet they all have contributed to steering the IWC toward conservation.

The 1970s witnessed rapidly growing international awareness of the need to protect the environment. In 1970 the IWC established the principle of maximum sustainable yield, which required the recovery of stocks to higher levels.FN109 Although this principle was still conservationist, it constituted a bridge toward protectionism inasmuch as it specified no time limit on the recovery period for a badly depleted whale species. (A time-limited recovery period would allow whaling to resume even if recovery were incomplete.)

The twenty-third meeting of the IWC was held in 1971, just before the United Nations Stockholm Conference, a time when whale stocks were seriously depleted and still deteriorating. The U.S. Secretary of State, Alexis Johnson, calling the meeting critical, declared that the very concept of an international commission as an effective means of resolving the conservation problem was at stake. He pointed out that the United States had recently placed eight species of whales on the Endangered Species List and that it would no longer issue licenses to kill whales, citing the IWC's ineffectiveness as the reason. The IWC responded by recommending the introduction of the as yet dormant International Observer Scheme beginning in 1971-1972.FN110 The following year, for the first time, all members of the IWC were in attendance. Maurice Strong, Secretary-General of the Stockholm Conference, presented its resolutions.FN111

The Stockholm Conference on the Human Environment was convened by the UN General Assembly primarily to identify problems and coordinate solutions at that time; it was not meant to develop or endorse an action plan.FN112 Committee 2 of the conference, which dealt with the environmental aspects of natural resource management," recommend a ten-year moratorium on commercial whaling to allow time for whale stocks to recover. Japan opposed the recommendation and labeled the resolution that incorporated it as dramatic and emotional. In response, the Netherlands maintained that the recommendation was based on sound scientific advice. FN113 The protectionist spirit that pervaded the conference is evinced by its emphasis on man's "special responsibility to safeguard and wisely manage the heritage of wildlife."FN114 In the end, the resolution was approved and [pg39] the call for a ten-year moratorium on commercial whaling was included in the 
action plan adopted by the conference.FN115 Yet the IWC's Scientific Committee said that "a blanket moratorium cannot be justified scientifically."FN116

By the early 1970s, stocks of Antarctic whales were so badly depleted that, assuming a total and effective ban on whaling, it would take fifteen years of fin whales to recover to the optimum and fifty years for blue whales.FN117 Serious questions were raised about the ability of the IWC to regulate and restrict whaling, and proposals were made calling for the United Nations to assume jurisdiction and control.FN118 Although never formally placed before the IWC, these proposalstogether with the resolution calling for a ten-year moratorium on commercial whaling-helped increase the pressure on the IWC to change its policies and even to consider amending the Convention. In sum, the Stockholm Conference may be seen as marking a pivotal point between conservationism and protectionism, a view reflected in the words of Dr. Robert M. White, who spoke for the United States: "World whale stocks must be regarded as the heritage of all mankind. . . ."FN119

The next five years witnessed a serious conflict between nonwhaling and minor whaling states on the one side, and major whaling states on the other side, as the former attempted to change the basic policies of the IWC from conservation to protection. FN120 In 1973, at the twenty-fifth meeting, the Scientific committee repeated and elaborated on its view that there was not biological need for a complete moratorium on commercial whaling and that such a move would work against the objectives of the Convention.FN121 It further drew attention to the lack of scientific evidence of adverse effects on the ecosystem. The representative of the International Union for the conservation of Nature and Natural Resources (IUCN), however, pointed out that "the use of a resource belonging to all nations for the marginal benefit of relatively few people seemed unjustified."FN122 The United States observed that "whales come under no man's exclusive national jurisdiction and as such have to be an international trust in whose disposition all nations should have a voice.FN123

At the IWC's meeting in 1974, the United States again called for a ten-year moratorium on whaling, a proposal that was seconded by Mexico. Though the proposal was rejected,FN124 it did succeed in generating a compromise that advanced [pg40] conservation interest. Representatives of the United Nations Food and Agriculture Organization (FAO), the United Nations Environment Programme (UNEP) and the IUCN were now allowed to comment formally whenever invited to IWC meetings.FN125 The Scientific Committee established two subcommittees to work on proposals for the International Decade of Cetacean Research.FN126 This active involvement of UNEP and the IUCN in marine mammal management was the key to future improvements in the IWC's conservation efforts.

At the next year's meeting, the Scientific Committee worked on New Management Procedures (NMP), which required the setting of sustained management stocks, initial management stocks and a protection stock. Proposals for revising the Convention were also considered, but no substantive progress was made. By the IWC'S 1977 meeting, UNEP had succeeded in its quite work of making management bodies aware of the interrelationship of environmental problems generally called "ecosystemic effects." Additionally, the presence of the media at the meeting prompted exposure of gaps and inadequacies in the IWC's regulatory efforts.FN127

\section{The Protection Stage: 1977-1982}

At some point the attitude we have been associating with "protection" overtakes the psychology of "conservation." Arguably, this important mental shift occurred sometime during the period from 1948 to 1982 - perhaps at the time of the Stockholm Conference of 1972. By 1977, the protection- 
ist sentiment appears to have emerged as dominant over that favoring conservation and its precursor, regulation.

Events outside the IWC catalyzed the change in attitude. As important as the Stockholm Conference of 1972 was the finalization of the concept of the 200-mile fisheries zone at the UN Conference on the Law of the Sea in 1977.FN128 Although entitling coastal states to such an extensive exclusive zone for fishing might appear to have set back the cause of international controls, it also gave rise to the possibility that the majority of states might ban whaling in their zones. Faced with this dilemma of internationalization versus nationalization, Japan, a pro-whaling state, decided to champion internationalization. At the IWC it argued that international management of whale stocks might collapse if states used the 200-mile zones to implement their own ideas about whale management. Australia met this argument with diplomatic finesse at the 1977 meeting of the IWC. It pointed out that Article 54 of the Revised Single Negotiating Text of the Law of the Sea Convention dealt with highly migratory species and marine mammals, giving coastal states the absolute right to prohibit, regulate and limit the exploitation of marine mammals in their respective proposed 200mile exclusive economic zones. However, the article gave the same right to an "international organization as appropriate." Thus, [pg41] the article did not negate the legal role of the IWC. FN129 In effect, Australia was saying that coastal nations could restrict whaling and the IWC could impose international restrictions as well without conflict. Obviously, this argument could not satisfy Japan's hidden agenda (to combat the growing prohibitory movement), but it helped isolate the minority of pro-whaling states like Japan that were attempting to play off the causes of internationalization and nationalization against each other.

Also in 1977, other outside influences began to make their presence felt by the IWC. The secretariat of the Convention on International Trade in Endangered Species (CITES)FN130 transmitted the report of its first meeting, highlighting the characterization of certain whales as endangered species, to the IWC. And the negotiation of the Convention for the Conservation of the Antarctic Marine Living Resources, attended by the IWC as an observer, resulted in the establishment of an organization with competing interests and objectives.FN131

An undramatic, but significant, event at the IWC's 1977 meeting was the reporting out of the Scientific Committee of an earlier IUCN resolution that suggested replacing the principle of maximum sustainable yield. The resolution provided in part as follows:

1. The eco-system should be maintained in such a state that both consumptive and nonconsumptive values can be realized on a continuing basis, ensuring present and future options, minimizing the risk of irreversible change and long-term adverse effects;

2. Management decisions should include a safety factor to allow for limitation of knowledge and imperfections of management. ...FN132

In short, the eumetric criticism of maximum sustainable yield in 1958FN133 had now osmosed into an official resolution. Clearly, MSY does not adequately take into account long-term adverse effects, limitations of knowledge and imperfections of management. To the extent that the Scientific Committee reflected the philosophy of the IWC, it was beginning to acknowledge the existence of natural fluctuations and ecosystem effects that throw scientific doubt upon the quantitative approach of MSY. Since any "soft" attack upon a quantitative approach suggests the philosophically alternative qualitative approach, this debate about MSY signaled the scientific equivalent of a movement from the traditional notion of conservation to the more radical notion of protection. 
In the eumetric spirit, the 1977 meeting instituted an outright ban on aboriginal whaling of the Arctic bowhead whale, which was acknowledged to be the most endangered whale species.FN134 However, this ban lasted only until the next meeting [pg42] of the IWC, when it was lifted at the request of the United States where various indigenous groups had instituted legal action in the courts alleging denial of their constitutional rights.FN135 Since the United States had been the principal proponent of the moratorium, its request for permission to allow aboriginal whaling weakened its general stance. FN136 Peru advanced two proposals for a moratorium; however, these were withdrawn when it became obvious that they would be defeated. FN137

At the next meeting, in 1979, when the membership of the IWC had expanded to twenty-three, FN138 Australia and the United States proposed a worldwide ban on commercial whaling. In a letter to the Commission, the U.S. President urged it to take "effective action to ensure the survival of the great whales."FN139 The Australian commissioner announced the intention of the Australian Government to oppose whaling both domestically and internationally, and to prohibit whaling in its proposed 200-mile fishing zone. The new policy, the commissioner said, represents a "change in emphasis from one of the conservative utilization of whale stocks to promoting a policy of banning whaling and protecting whale populations. "FN140 The commissioner enumerated as reasons for this change the potentially high intelligence of whales, a growing community conviction of the immorality of whaling, the imminent availability of substitutes for whale products, the inhumane way that whales are killed, and the risks to the maintenance - and even survival — of some species. FN141

Similar positions were taken at the meeting by New ZealandFN142 and the Seychelles,FN143 but only one outright ban was imposed — on pelagic whaling — and it excepted minke whales and whaling on land stations.FN144

Prominent developments in the period of emergent protection (1948-1980) were the concept of New Management Procedures for establishing catch quotas, the substantial growth in membership of the IWC, and the involvement of, and interference from, other international organizations expressing increasingly militant opposition to whaling. CITES has been one of the most important of the latter organizations.FN145 The basic objectives of the Convention are to protect species [pg43] threatened with extinction, listed in its Appendix I, by prohibiting trade in those species or products derived from them; to control trade in species that are not yet threatened but may be threatened in the future, listed in Appendix II; and to protect and control trade in species that are not listed in the first two appendixes but are regulated by a party to the treaty.FN146

For some time the IWC protected some species more stringently by placing them under the protected stocks, while CITES listed them only in Appendix II (species that might be threatened). FN147 Thus, at its first meeting, in 1976, CITES listed only gray, blue, humpback, and right whales in Appendix I.FN148 At its second meeting, in 1979, all cetaceans were added to one appendix or the otherFN149 and the secretariat was authorized to consult with the IWC regarding cetaceans, and more specifically, regarding proposals to amend Appendixes I and II.FN150 On the basis of comprehensive data furnished by the IWC's Scientific Committee, CITES at its third meeting, in 1981, placed all IWC protected species in Appendix I. These included gray, blue, humpback, right, sei, fin and sperm whales.FN151 By 1981, CITES listed even more species in Appendix I than were on the IWC's protected stock list. Outflanked on its left by CITES, the IWC reacted by moving ever closer to the CITES position. 
By 1980, moratorium was destined to be the IWC's topic of the decade. That year, at the thirtysecond meeting,FN152 with twenty-four members attending, three different proposals for moratoriums were introduced: a worldwide moratorium, a moratorium on commercial whaling, and a moratorium on sperm whaling. The first had originally been submitted by Australia in 1979. In the meantime Australia had indeed adopted the Whale Protection Act, which prohibits the killing, capturing or injuring of cetaceans within its 200-mile fishing zone, and a ban on the importation into Australia of all whale products or goods was to be imposed as of January 1981.FN153 The Australian proposal was seriously considered and examined by a working group whose report indicated that a worldwide moratorium could result in the direct loss of over 7,000 jobs and an indirect loss of over 35,000 jobs. Although the report was vigorously debated, no action was taken. FN154 Both [pg44] the U.S. proposal for a moratorium on commercial whaling and the proposed moratorium on sperm whaling failed to receive the requisite majority vote.FN155

Membership in the IWC increased by 33 percent by the next year's meeting in 1981.FN156 Such new members as Costa Rica and India made strong statements in favor of preserving the whale.FN157 Clearly, the increase in membership had brought extra support for conservation policies. The United Kingdom, with the support of the United States, Sweden, France and New Zealand, once again proposed an indefinite global ban on whaling, and once again it failed to receive a majority.FN158 Another UK proposal, for an indefinite moratorium in the North Atlantic, also failed,FN159 as did a proposed indefinite moratorium on pelagic whaling for minkes after the 19831984 seasonFN160 and a proposed worldwide phaseout of commercial whaling over a five-year period.FN161

The only proposal to succeed, which it did overwhelmingly, was submitted by the United Kingdom, France, the Netherlands and the Seychelles. It imposed an indefinite moratorium on the taking of sperm whales,FN162 whose fisheries by then were virtually denuded.

In December 1982, the long-awaited, comprehensive United Nations Convention on the Law of the Sea was completed at Montego Bay and opened for signature.FN163 Although as of this writing it has not yet entered into force, its provisions have had a direct impact upon the content of customary international law.FN164 Notable for present purposes is Article 65: "States shall co-operate with a view to the conservation of marine mammals and in the case of cetaceans shall in particular work through the appropriate international organizations for their conservation, management and study."FN165 This provision shows a marked improvement [pg45] over the Geneva Convention on Fishing and Conservation, which did not specifically address the plight of marine mammals. Another significant improvement is the conspicuous absence of the "optimum utilization" requirement, or MSY. Thus, Article 65 tends to infuse "conservation" with a meaning other than MSY and closer to the eumetric conception that we have discussed. The singling out of cetaceans not only suggests a heightened sense of international responsibility toward whales, but also may constitute a legal gesture toward giving whales "standing" in international law beyond the limits of the IWC. Article 65 may be interpreted as putting whales first and international organizations second; the article makes the IWC legally significant only to the extent that it is an "appropriate" organization devoted to the conservation, management and study of whales.

\section{The Preservation Stage: 1982-1990}

We have attempted so far to show that the initial regulation of whaling was transformed into conservation (for the health of the whaling industry), which in turn was overtaken by a drive for 
protection (for the survival of whales themselves). The protectionist attitude and the conservationist attitude have much in common, even though their psychological motivations are different. Together they account for the momentum seen in the activities of the IWC from 1946 through 1982. The protectionist attitude allows for "reasonable" exceptions. For instance, the protectionist will try hardest to protect whale species that are endangered, while making trade-offs with whalers on stable and growing species. The protectionist might concede that a certain amount of whaling is commercially necessary, so long as the activity is restricted to stable or even growing species. In this respect, protectionists and conservationists find considerable common ground.

We now introduce a form of protectionism that is largely incompatible with conservation. For want of a better label, we call it "preservationism." Unlike the protectionist, the preservationist will not admit of exceptions - reasonable or otherwise. The preservationist wants to ban all whaling, irrespective of whether a particular species is stable or endangered, an attitude that is clearly incompatible with the industry of whaling. Whalers and preservationists view each other as mortal enemies - as is dramatically reflected in the "whale wars" that began approximately in 1978 and have since escalated.FN166

Eight new members, all nonwhaling states, joined the IWC by its thirty-fourth meeting, in 1982, FN167 making the prospects for a moratorium brighter than ever before. The Seychelles announced that it was amending its position in the Commission in favor of a phase-out or negotiated cessation of commercial whaling because this course would "facilitate the adjustment that whaling nations will have to make if the whale is to be saved from extinction, and at the same time [would] safeguard the future work of the Commission as a growing alliance of nations committed to preserving all cetaceans for posterity."FN168 A diplomatic move, the Seychelles proposal sought zero quotas for all commercial whaling by the 1986 [pg46] coastal and 1985-1986 pelagic seasons, subject to review thereafter.FN169 The proposal was approved by a vote of twenty-five in favor, seven against and five abstentions.FN170 A three-year period was allowed to give whaling states an opportunity to phase out their commercial activities gradually and to cope with the economic impact of the moratorium, in accordance with the Preamble to the ICRW. FN171 The ban on "commercial" whaling was understood to exempt aboriginal subsistence whaling, especially of the endangered bowhead species by the Inuit in arctic Canada, Alaska, Greenland and Siberia.FN172

An action taken by the European Economic Community at about the same time may have helped to enforce the moratorium. A regulation entitled Common Rules for Imports of Whales or Other Cetacean Products established an EEC ban as of January 1, 1982.FN173 Since the ICRW does not include nonstate parties, passage of the regulation cannot be linked directly to discussions in the IWC. Rather, it resulted from the EEC's obligation to CITES, to which it is a party. Under its own Treaty,FN174 the EEC is bound to enforce the prohibition on the entrance into the European Community of whale products that fall under CITES Appendix I. The EEC regulation bans the commercial import of such products without proper licenses.

The next IWC meeting, in 1983, is important for the responses of the states that had opposed the 1982 amendment of the schedule. Of the seven that had opposed the moratorium, four filed formal objections (Japan, Norway, Peru and the USSR), while three others, together with one of the absentees (Brazil, Chile, Iceland and the Republic of Korea), decided not to file objections. After Peru decided to withdraw its objection,FN175 only Norway, Japan and the USSR were left as formal objectors. The United States at this time notified both Norway and Japan that it was initiating certification under the Pelly AmendmentFN176 because they were diminishing the effect of a conserva- 
tion treaty to which the United States was a party. The amendment required that the United States impose an embargo on the certified nations' fishing rights in its 200-mile economic zone and ban the importation of fishing products from those nations. This drastic step was designed to bring both Norway and Japan in line with the conservation measures implemented by the IWC. However, the Soviet Union was immune from this type of pressure because it did not export fisheries products to the United States.FN177

[pg47] CITES continued to exert a catalytic effect upon the IWC. At its fourth meeting, in 1983, the first after the IWC's adoption of the commercial whaling moratorium, CITES added seven cetacean species to Appendix I, including some of the minke and pygmy right whales regulated by the IWC. The inclusion of other species, though listed in 1983, was to enter into effect on January 1, 1986, the effective date of the total ban on commercial whaling.FN178 The parties to CITES thus demonstrated strong support for ending commercial whaling.FN179

In the effort to ban commercial whaling, CITES had certain advantages over the IWC, with which it continued to cooperate closely. Its large membership could muster considerable support for the protection of endangered species, whereas the IWC's limited membership was long dominated by the whaling countries. The parties to CITES generally subscribed to protection and were required to enforce wildlife protection measures through domestic laws. They were far more willing than members of the IWC to comply with measures to protect marine mammals. Finally, the CITES prohibitions on the covert or overt trade in whales and whale derivatives have been effective. One might cautiously say that CITES had become the enforcement mechanism for achieving the then-stated objective of the IWC, that is, a moratorium on commercial whaling.

At the IWC's thirty-sixth meeting, in 1984, Brazil reversed its stand of 1982 and decided to support the moratorium.FN180 Japan, however, adhered to its earlier position and objected on technical and legal grounds to the imposition of the moratorium. Japan also likened Japanese whaling to subsistence whaling elsewhere and insisted that it needed to be perpetuated in the socioeconomic interest of the Japanese coastal community.FN181 Of the other states that had opposed the moratorium in 1982, the Republic of Korea reported that despite internal objections and economic problems, it would comply with the measure;FN182 the Soviet Union again objected to the moratorium on technical grounds.FN183

Japan shifted its position at the next year's IWC meeting. While maintaining its informal objection on technical grounds, Japan said that "in order to avoid a head-on conflict" with the United States, it would withdraw its formal objection to the moratorium. n184 The Philippines, however, which the previous year had indicated its wish to continue scientific research on whales, now revealed its plans to resume whaling once it was determined that stocks were not endangered. n185 Another important announcement came from the Soviet Union, which stated that it would temporarily stop commercial whaling in the Antarctic, for technical reasons, though it maintained its objection based on the illegality of the moratorium decision.FN186

Meanwhile, sentiment against commercial whaling continued to mount in the IWC. Speaking as a new member, in a letter to the Commission Indian Prime Minister Rajiv Gandhi pointed out that India had joined as a nonwhaling member only to "join other nations . . . in their endeavor to save this most fascinating and remarkable member of our planet's living fraternity."FN187

[pg48] At the next meeting, in 1986, Brazil announced its presidential decree of January 1, 1986, enforcing the moratoriumFN188 and Japan informed the parties that it would cease its com- 
mercial activities the next year.FN189 Oman was able to proclaim that "whales are safer from human harm now than at any time since the beginning of modern pelagic whaling some sixty years ago."FN190

\section{The Emerging Entitlement Stage}

The five-year moratorium on commercial whaling was revaluated and renewed by the IWC's annual meeting in Noordwijk, which ended on July 6, 1990. Such traditional whaling nations as Japan, Norway and Iceland pressed for the establishment of quotas on certain species that they argued were at harvestable levels. The IWC, however, refused to alter the moratorium in any way. It also denied Japan's request for an allowance for small-type coastal whaling (i.e., whaling by the use of hand implements, as opposed to "pelagic whaling," which uses factory ships). The Commission condemned as unnecessary the killing of whales for research and it asked Norway and Japan to reconsider their policies in this regard.FN191 These actions led to threats by Japan and Iceland to pull out.

Virtually all commercial whaling activity has now ceased.FN192 The moratorium, however, only applies to great whales (the ten largest species). For the first time, the IWC agreed to study "small cetaceans," including dolphins, porpoises and small whales. In addition, it passed a resolution supporting the UN General Assembly's initiative to phase out large-scale drift-net fishing within two years.FN193

Although a total moratorium would be a triumph for preservationists, the concept of moratorium does not entitle whales to the right to life, because a moratorium implies temporal limitations (even if extendable) upon whaling activities. That a moratorium can end, with a resumption of whaling, is explicit in the "global commons" recommendation of the World Conservation Strategy, an organization commissioned by the United Nations Environment Programme.FN194 The recommendation called for a moratorium to "be extended to all commercial whaling until: the consequences for the eco-systems concerned of removing large portions of the whales' populations, and such populations' capacity for recovery, can be predicted."FN195

[pg49] Thus, the preservationist movement cannot be the last stage of our story. It is merely the present stage, but it contains the seeds of the final stage, which we have labeled the "entitlement" stage. Preservation is transmuted into entitlement when the moratorium becomes permanent, at which point it is no longer definitionally a "moratorium" but, rather, may be termed an entitlement to life. Yet the new entitlement stage involves an important shift in philosophy. By claiming that whales are "entitled" to life, the entitlement philosophy recognizes this right as belonging to, or even coming from, the whales themselves. In contrast, the preservationist views the permanent moratorium as bestowed by humankind upon whales; the rights come from the people, and the people are exercising their right to preserve whales. Consequently, the entitlement stage may involve the most radical philosophical shift of the progressive stages that we have recounted in this article, even though historically it represents only an incremental advance over preservationism.

The six stages we have recapitulated - free resource, regulation, conservation, protection, preservation, entitlement - may be viewed as a progression from self-interest to altruism,FN196 or from individualism to communalism,FN197 but we suggest that they are better conceptualized as a broadening of international cultural consciousness.FN198 The whalers of the early twentieth century were persuaded to accept the second stage - regulation - even though many of them found that it hindered their individual freedom. They accepted it on the rational ground that they them- 
selves might destroy their livelihood as a whole unless certain common restrictions were placed on the whaling enterprise. This rational conclusion constituted an increase in breadth of consciousness, from "do anything we want," to "don't do some things that might hurt other whalers and eventually ourselves." Similarly, the step from regulation to conservation met resistance; whalers had to be persuaded that long-term conservation would benefit the industry as a whole, which in turn would enhance the economic interests, or at least prospects, of each whaler. Again, consciousness was broadened. And so it has continued with each of our six analytic stages. In the fifth and sixth stages, whalers face the loss of their entire enterprise, yet the increase in consciousness now embraces the environment as a whole, the planet on which we all live. In this respect, whalers should be no different from anyone else; everyone's self-interest is in a stable and viable ecosystem. Hence, it would be a mistake to conclude that the transition from the first stage to the second, or for that matter from any one stage to the next, has been more difficult or historically important than any other.

Although the distance covered between stage one and stage six amounts to a catastrophic change - from uninhibited freedom to prohibition - the change from any one stage to the next was incremental, depicting the same underlying psychological and philosophical process of increasing breadth of consciousness. For this reason, we contend that what we have denominated as the last stage — entitlement - [pg50] is not qualitatively different from the others. Rather, it is part of a relentless, historically necessary progression. We may or may not be in the final entitlement stage today - different people will think differently — but its seeds were planted in each of the five preceding stages.

Readers who are familiar with international jurisprudence will recognize that in our discussion of the changing psychology and breadth of consciousness, we have implicitly been sketching a trend in the component of customary international law called opinio juris. The development of international custom is inevitably a dynamic process, and the seeds of a future conflict-resolving synthesis are always present in the clash of thesis and antithesis that constitutes the claim conflicts among states. To anticipate a customary trend is to argue that, in a sense, it already exists. We have seen, in the history we have recounted, the practice of states (reflected through their whaling activities) moving through six stages that are best characterized as increases in international breadth of consciousness. This combination of practice and consciousness formally constitutes the material and psychological elements of general custom. What states do becomes what they legally ought to do, by virtue of a growing sense that what they do is right, proper and natural.FN199 The dawning sense of duty to the environment - to protect the ability of our small, green planet to sustain life is evidence of a sense of obligation that constitutes the opinio juris component of binding customary international law.

Hence, if our argument in this section is accepted, we have sketched more than a politicalcultural history of a relentless increase in breadth of consciousness about whales. We have suggested an opinio juris - a growing sense of international legal obligation toward whales. In the current stage of that progression, nearly all nations accept the obligation of preservation. And in this consensus of preservation, we suggest that there is the incipient formation of the final, decisive stage - the entitlement of whales to life. Whether that final stage has already arrived cannot be definitively determined. But we argue that in its inevitability it has already been anticipated in the law. 
If we are correct, this anticipation of a stage of entitlement for a nonhuman species in international law is a revolutionary development. It takes seriously the fact that human beings are open systems - that our lives are dependent on our environment. The human race will live or die as the ecosystem lives or dies. International law can no longer be viewed as an artifact exclusively concerned with state and human interactions against a mere background called the environment. Rather, other living creatures in the environment are players in a new and expanded international legal arena.

\section{RIGHTS AND ENTITLEMENTS}

The middle four stages of the legal progression that we traced in part II - from (2) regulation to (3) conservation, to (4) protection, to (5) preservation - might be thought to serve whales well enough for all practical and legal purposes. What [pg51] need is there to move to the sixth, entitlement, stage? Specifically, what particular value is added by ascribing rights to whales, as distinct from recognizing a duty of nations and individuals toward whales?

We contend, first, that it is intelligible to regard whales as rights holders and, second, that viewing the rights in this way makes a difference. On both these points, we employ the pioneering analysis of Christopher Stone.FN200

History has seen a widening of the circle of rights holders. When infanticide was freely practiced, infants had no rights; now of course their right to life is protected in nearly all countries by the law against murder. Convicted felons used to be stripped of all rights; now they have certain basic protections (e.g., equal medical care). The laws of most countries have seen a gradual progression in ascribing rights to aliens, married women, the mentally enfeebled and racial minorities. FN201 Rights have also been extended to inanimate, intangible entities: trusts, corporations, joint ventures, partnerships and municipalities.FN202 In recent years corporations have even been prosecuted and convicted of crimes. n203 International law classically regards nation-states as having rights and responsibilities. In this broad context, there is nothing strange about recognizing the rights of whales - creatures that are more animate than corporations, more communicative than infants and mentally enfeebled persons, more communal than the society of nations, and perhaps more intelligent than the smartest human beings.

Professor Stone has suggested the important differences that would accrue if we ascribed rights to natural objects in the environment. The first is what we might call the aspect of generality: that having rights is a generalized legal competence, whereas being the beneficiary of the obligations of others breaks down into a series of specialized, specific rules. For example, suppose a person signs a contract with a corporation, then attempts to avoid his obligations under the contract by pointing to the corporation's charter and showing that the terms of the contract were, strictly construed, ultra vires.FN204 Under a strict interpretation of the idea of incorporation, the corporation only exists by virtue of the specific competences listed in its corporate charter. But such an approach would hardly ever be adopted by any court.FN205 Instead, the corporation is said to have certain generalized "rights," including the right to enter into contracts. These rights bestow a competence on the corporation that, in Professor Stone's words, is flexible and open-ended.FN206

Second, the idea of having "rights" includes a notion of moral rights that can inform existing law or even push it in a certain direction.FN207 Take, for example, a battered wife suing her husband in the nineteenth century. Courts routinely dismissed such cases on the ground that they had no jurisdiction over what happened [pg52] in the home, and in any event a wife had an adequate 
remedy under the laws of divorce. But at some point, courts changed their approach and began recognizing tort claims by wives against their husbands. Suppose that just prior to the turning point an attorney advised a wife that she had no legal right to sue her husband in tort. The advice, though grounded in precedent, would have been misleading since, by hypothesis, in the very next case the court "found" such a right. What happened is that the court accepted the powerful moral claim of right and recognized it as somehow subsisting in the common law all along, even though legal precedent was to the contrary. We say that the court "articulated" the preexisting right, much as we argued that an international court could articulate an entitlement of whales arising from the customary law practice of their preservation.

Third, the burden of proof in litigation and negotiation can turn on which party is a rights claimant. Courts may be predisposed to giving a far more "liberal" construction of applicable rules to a party that claims to be asserting rights than to one that claims to be a third-party beneficiary of asserted rights. Even the rules regarding burden of proof, Professor Stone suspects, would be more liberally interpreted in favor of a rights claimant.FN208

Fourth, the development of a jurisprudence regarding whales is more likely if whales are perceived by courts as rights holders, just as a jurisprudence of corporate law has developed as a result of viewing corporations as legal entities entitled to sue and be sued and even to be prosecuted for corporate crime.

Finally, standing is facilitated for rights holders. Standing may be a lesser problem in American law than in the law of many other countries because of the separation-of-powers tradition of contesting many forms of governmental action in the courts. Yet even in U.S. courts when the protection of whales arises, the need to assert harm to one's own interests, as opposed to the interests of whales, may exert a subtle negative influence upon the petitioners. In Japan Whaling Association v. American Cetacean Society,FN209 although the Supreme Court found (in a footnote) that the American Cetacean Society, Greenpeace, Friends of the Earth and other environmental organizations had "alleged a sufficient 'injury in fact' in that the whale watching and studying of their members will be adversely affected by continued whale harvesting,"FN210 the Court ultimately held against those organizations on the merits.FN211 Watching and studying whales seems a slender reed on which to mount a lawsuit to protect whales.FN212 The real party in interest is the [pg53] whale. Perhaps the very tenuousness of the "standing" the Supreme Court allowed the environmental groups contributed to the lack of empathy toward whales in the Court's ultimate decision on the merits.

For these reasons, and similar ones that could be adduced, the extension of legal rights to whales would have significant legal consequence. To move from "preservation" to "entitlement" is not just a way of talking. Rather, it acknowledges the creation of a new subject of international law.

A "right" may be legal or moral or both. The attempt to draw a sharp distinction between legal and moral rights often founders on two grounds.FN213 First, as H.L.A. Hart has demonstrated, moral considerations influence the content of law over time.FN214 Second, there may be a deeper connection between law and morality than positivists such as Professor Hart are willing to admit. Although this connection may not be a "necessary" one in the substantive sense of Cicero or in the procedural sense of Lon Fuller,FN215 it exists in the claim of legitimacy that the law makes - a claim that surpasses that which can be enforced and spills over into the realm of that which is morally persuasive.FN216 For these general reasons, we have not attempted in this article to draw lines between the moral and the legal in our discussion of the emerging rights of whales. Although we 
have indicated when we are primarily talking about moral rights and when we are primarily talking about legal rights, the considerable degree of overlap between the two, we submit, reflects the way a norm develops over time.

Nevertheless, for our discussion of the final stage of the rights of whales, we deliberately chose the term "entitlements" instead of "rights." By entitlements we mean legally enforceable rights. An entitlement may overlap with morality; but if it is not legally enforceable, it is not an entitlement no matter how strong the moral considerations in its favor. In this respect, we borrow and modify the definition of entitlements by Calabresi and Melamed in their leading article on the subject.FN217 They say that the first aspect of "entitlement" occurs whenever the state is presented with the conflicting interests of two or more people, or two or more groups of people; the state must decide which of the conflicting parties will be entitled to prevail.FN218 The second aspect is intervention by the state to enforce the decision. Extrapolating this definition to the international legal system, we claim that the whale, as a sentient being, is in the process of being assigned an entitlement to life. If we are correct, then in any conflict between whale and whaler, the latter lacks, or soon will lack, any entitlement to hunt and kill the whale. As to enforcement, the international community is at present intensifying its efforts to protect the whale, both internationally (e.g., through the IWC) and nationally (e.g., through import restrictions and peaceable countermeasures such [pg54] as denial of discretionary fishing privileges to fishermen from nations that engage in whaling).

Calabresi and Melamed discuss "inalienable" entitlements - property interests that cannot be transferred between a willing seller and a willing buyer — such as body parts and vital organs, and one's children.FN219 On the other hand, no entitlement is absolute. For example, a murderer's entitlement to life cannot prevail against the claim of a state to enforce its law on capital punishment. If we take whales' entitlement to life seriously, we cannot allow it to be defeated by any lesser countervailing entitlement. However, if a countervailing entitlement seems to be of the same or greater magnitude, a serious problem in moral and legal judgment presents itself. We turn now to two potential conflicts of this type.

\section{COUNTERCLAIMS}

The acknowledgment that whales have an entitlement to life directly conflicts with at least two types of counterclaims that have recently been advanced as justifying the hunting and killing of whales. The serious assertion of these claims - for "scientific research" and "aboriginal subsistence whaling" - indicates that even when ecological consciousness can be assumed, investing whales with an entitlement to life is controversial. In a brief comment on these two claims, Professor Falk admits that they are "complex even when one is considering the plight of particular species of whales faced with a prospect of extinction."FN220

\section{"Scientific Research"}

In the 1980s, Japan, Iceland and the Soviet Union made claims for exceptions to the whaling moratorium on the ground of scientific research. Perhaps the most articulate justification of this position is an article by Kazuo Sumi, professor of international law at Yokohama City University. FN221

Professor Sumi claims that Japan is deviating from the IWC's moratorium on commercial whaling because its purpose is scientific rather than commercial. Although he does not define "scientific research," he indicates at several places in his article what that term comprises. At one place, he 
says, "Data and information on the resource state of whales are essential for rational management." FN222 Later he indicates that the aim of the Japanese research program is "to obtain estimates of various biological parameters, especially of age-specific natural mortality. Additionally, it [is] also intended to elucidate the role of whales, (namely, the sperm whale and the minke whale) as a key species in the Antarctic marine ecosystem."FN223 Asked why most of this research could not be done with photography and non-lethal tests, Sumi invokes the authority of some members of the IWC's Scientific Committee sympathetic to the Japanese position, who asserted that "the analysis of material (particularly ear plugs, ovaries, and stomach contents collected from dead whales) could not be carried out through non-lethal research."FN224

Sumi's claims clearly demonstrate that the purpose of the scientific research program is not to discover new facts about whales but, rather, to prove to the IWC that the particular whales that Japan is hunting are not an endangered species. Sumi in effect concedes this point by stating that "Japan emphasized that the [pg55] results to be obtained . . . will provide a scientific basis for resolving problems facing the IWC which have generated confrontation among the member nations due to the divergent views on the moratorium."FN225 Under its program, Japan proposed an "annual sample size" of 825 minke whales and 50 sperm whales in Antarctic waters; in the two years of "sampling" between 1987 and 1991, this would amount to a kill of 1,650 minke whales and 100 sperm whales.FN226 But Sumi does not explain what would happen if the very "sampling" process he describes destroyed the species. From a logical point of view, if the "sampling" is scientifically necessary to determine the facts about whether certain species of whales should be on the IWC's endangered list, Japan must concede that in advance of the sampling no one can be sure whether the particular species is endangered. Since Japanese whalers are concededly killing all these whales in a state of a priori uncertainty about whether the species is endangered, one result might be that the process of lethal "sampling" itself could reduce a species of whales below the critical level necessary for reproduction.FN227 The Japanese scientists would then have to report that as a result of their research efforts on whether sperm whales (for example) could survive extinction, that particular species had become extinct.

Sumi argues that, at least as far as the minke whale is concerned, it appears to inhabit the oceans in large numbers and is far from the point where it should be listed as an endangered species.FN228 Yet when he considers the suggestion that Antarctic whales could be scientifically studied by means of photography, he objects that minke whales "have quick mobile behaviour and a large stock size and it is not known whether they have identifiable individual characteristics. "FN229 Noticeably, Sumi does not consider how Japanese whalers - assuming they are hunting only for minke whales - can be sure that the creatures they shoot with exploding harpoons are minke whales. For if these whales cannot be identified by photographs, and if it is unsure that they have identifiable individual characteristics, how can whalers on a boat know that it is the minke whale they are killing and not the similar-shaped and -sized beaked whale, killer whale or gray whale?

A different sort of justification advanced by Sumi is Japan's domestic law, which in November 1987 dissolved Nippon Kyodou Hogei Co., the last remaining Japanese whaling company, and within thirty days established the Institute of Cetacean Research, a nonprofit organization. This change in domestic legislation did not, however, result in changing the claims for exemptions made by Japan before the IWC; the program of "scientific research" continued unabated. Sumi concedes that the Institute of Cetacean Research, after hunting and killing the whales, and after the scientists have conducted their research on the carcasses, sells the whale meat and byproducts on the Japanese market. But he adds that any profits resulting from these sales "revert back to the research pro- 
gram."FN230 Thus, the new Institute of Cetacean Research may pursue the same whaling program as did Nippon Kyodou Hogei Co., so long as profits are poured back into the institute. Sumi does not tell us whether the Nippon Co. also retained its whaling profits (as it might have done instead of distributing them to shareholders in the form of [pg56] dividends).FN231 Nor are we informed whether the Institute of Cetacean Research will build bigger and better whaling vessels, from the profits of its sales of whale meat, in anticipation of the day that the IWC's moratorium is lifted. All we are told is that, by a stroke of domestic legislation, Japan is no longer engaged in "commercial whaling" and thus is not subject to the IWC's moratorium on commercial whaling.FN232

Three additional arguments in favor of Japan's whaling policy are found in Sumi's article. First, he contends that the United States, which has taken the lead in criticizing Japan's policy, has been gravely inconsistent. By stressing a ban on "commercial whaling," the United States has managed to exempt Alaskan aboriginal subsistence whaling. The United States has tolerated the hunting by the Inuit of the bowhead whale, a truly endangered species, while the minke whale hunted by the Japanese is arguably far from being endangered.FN233 In the next section we shall criticize the aboriginal exemption. But even if the policy of the United States is wrong, that is no justification for the Japanese policy. And in any event, the U.S. tolerance of the subsistence hunting of bowhead whales by aboriginal Alaskans has no relationship whatsoever to the claim by the Japanese that their whaling policy is dedicated to scientific research.

Second, Sumi invokes "the sovereign rights of states" in objecting to certain specifications on scientific research laid down by the IWC's Technical Committee.FN234 But "sovereign rights" is a rhetorically overused and ill-fitting concept in discussions of international law. If any state could claim sovereign rights in the teeth of an international norm to the contrary, international law (as a set of general norms binding on states) would not exist.FN235 However, Sumi may be making a more modest point in invoking sovereignty — that the IWC has no treaty power to prohibit Japan from killing whales in violation of the IWC's moratorium if Japan has filed a timely request for a special permit. Whether the internal legal procedure of the IWC under the ICRW sustains this argument is a matter of treaty construction. Sumi recognizes that the matter is not free from legal doubt in suggesting that one policy option for Japan is to ask the International Court of Justice for an advisory opinion as to whether, under the Convention, an IWC resolution can legally restrict the issuance of special permits by member countries to allow whaling.FN236 Within the IWC, it is true that a member country such as Japan retains all its legal rights under the ICRW. But as far as customary international law is concerned, what the IWC does as a whole is significant, not whether [pg57] what it does is valid as a matter of internal constitutive law.FN237 In this respect as well, a "sovereignty" objection has no force against an international norm.

Third and finally, Sumi claims that cultural bias is operating unfairly against Japanese whalers. The eating of whale meat in Japan is a function of "dietary customs, religious beliefs, cultural backgrounds and emotional sensibilities .... . For the Japanese people, the whale is not only a food source, but also a basis of culture."FN238 For example, he says that "baleens of the right whale have been used as an essential part of 'Bunraku,' Japan's traditional puppet theatre."FN239 The Japanese whaling industry uses all parts of the whale in a productive manner, whereas U.S. whalers in the eighteenth and nineteenth centuries made use only of whale oil. When it became less expensive to exploit petroleum, the United States could afford to abandon its wasteful whaling ventures and become conservation minded. 
This last argument is a clear example of an antientitlement perspective. Surely from the point of view of the whale, the fact that all of its bodily parts are exploited cannot make a moral difference. FN240 Or to state the matter differently, should the fate of a whale turn on whether its whalebone will be simply discarded or effectively utilized for theatrical purposes? One might argue that discarding the whalebone, "wasteful" though it is, may be preferable from an entitlement perspective. For the cultural use of the baleen in folk theater may well help to perpetuate and solidify a pervasive attitude among the population that the whale is meant to be killed for the artistic and gustatory benefit of humans. This attitude itself can thus contribute to the perpetuation of, or increase in, the hunting and killing of whales.FN241 But apart from the perspective one adopts with respect to these questions, this final argument, like Sumi's showing of the inconsistency of the United States policy, surely has nothing to do with whether the Japanese whaling policy is justified as a form of scientific research. Despite the many arguments ably advanced by Professor Sumi, it appears that he has not presented a single reasonable contention in favor of fairly labeling the killing of thousands of whales as a scientific research program.

\section{Aboriginal Subsistence Whaling}

If whales have an entitlement to life, what happens if indigenous people assert a competing entitlement to killing them for subsistence? This need has been asserted on behalf of the Inuit — the indigenous peoples of arctic Canada, Alaska, Greenland and Siberia, also known as Eskimos. The problem is poignant because the whales they hunt are the bowhead, an endangered species.FN242

[pg58] The case for the Inuit has been effectively presented by Nancy Doubleday.FN243 She cites Article 1(2) of the International Covenant on Economic, Social and Cultural Rights: "In no case may a people be deprived of its own means of subsistence."FN244 She attacks the IWC's quotas on aboriginal hunting of endangered species such as gray whales and bowhead whalesFN245 on the ground that the IWC "does not have express jurisdiction over subsistence whaling."FN246 The Inuit hunt "for food in order to survive, not for sport or pleasure."FN247 In the Inuit culture,

animals and their spirits are respected and shown honor according to tradition, but it is a dialogue, as the animals allow themselves to be taken only by those who respect them. A hunter who abuses or who fails to show respect to the animals he takes will not be successful in the hunt. Failure in the hunt is failure in life.FN248

From earliest times, Ms. Doubleday contends, the Inuit in practice were conservationists; they only hunted and killed whales as they needed them for subsistence. It was the commercial whalers of the nineteenth and twentieth centuries who severely depleted the bowhead species and endangered its survival. Commercial whalers abandoned arctic waters when the remaining bowheads were too few to make the expeditions profitable. Thus have the exploitative commercial whaling practices of the developed nations victimized the Inuit people. Having endangered the species, the commercial nations are attempting through the IWC to curtail the Inuit's historic right to subsistence whaling.

Doubleday does not go so far as to argue that the Inuit should be allowed to hunt the bowhead whale into extinction. She concludes by making the modest claim that "indigenous peoples must be a party to any discussions affecting their aboriginal subsistence rights."FN249

The conflict presented by Doubleday between indigenous peoples' subsistence whaling and what we have claimed is the whale's entitlement to life has so far been addressed only in the political arena. The United States, as we have seen, has taken a retrogressive position in favor of the Inuit, 
presumably on the basis that the Inuit of Alaska can vote whereas whales cannot. Leading environmental organizations such as the Sierra Club and Friends of the Earth have been, if anything, even less forthcoming than U.S. politicians. Although these organizations claim to be champions of the rights of whales, when it comes to the bowhead whale - a truly endangered species - they are uncharacteristically silent. Undoubtedly, the reason is their respect for the "rights" of indigenous people. These "political solutions" are thus not solutions at all; they are simply policies constructed upon expediency.

If we turn from the political sphere to the legal, some of the murkiness clears up. Doubleday's complaint about the jurisdiction of the IWC, like Sumi's, confuses intraorganizational constitutive rights with the lawmaking effect of the organization's activities in the international legal system. Moreover, she is not convincing in her attempt to justify Inuit hunting practices as showing respect and honor to the whales: no one asked the bowhead whether the gangs of men clubbing and harpooning them were demonstrating respect. Nor does it follow that because [pg59] exploitative commercial whaling practices were primarily responsible for endangering the bowhead, the Inuit are therefore free to pursue the species to extinction. Unfortunate though it may be that commercial whaling placed the Inuit's source of food in danger of extinction, the fact remains that no further killing of bowheads - whether by commercial fishing vessels or by the less technological methods of the indigenous peoples - can be justified. Finally, there is conflation and confusion in Doubleday's repeated linking of the Inuit's "subsistence needs" to the preservation of their "culture" and "way of life." No one claims that the Inuit would starve to death if they were stopped from killing whales. As Professor Stone's analysis reveals, it is not the lives of the Inuit that are at stake but, rather, their traditional life style.FN250 It appears that Doubleday has failed to make any rational argument for exempting the Inuit from the norms of international law, even though in closing she makes the emotional argument that the attempt to include whales in the "common heritage of mankind" under international law is "a kind of intellectual imperialism."FN251 In fact, all rules of law are a form of intellectual imperialism.

Many international lawyers are taking up the cause of indigenous peoples. As the statist conceptions of international law exemplified by Oppenheim give way to the humanist conceptions of the present day,FN252 overlooked voices deserve the greatest consideration. When the rights of indigenous people are suppressed in favor of exploitative commercial interests - as with the Indians of the Brazilian rain forests - the noblest sentiments of international lawyers should be brought to the service of those rights. But Doubleday's easy coupling of the predicament of the Indians of the Brazilian rain forest and the claims of the Inuit to hunt the great whales of the Arctic is unpersuasive. The Inuit's claims are at the expense of an overlooked voice - the anguished cry — of the sentient inhabitants of the deep. Doubleday would attempt to convince the reader that only one interest is at stake: that of the Inuit and their right to the "resource" of the great whales.FN253 But, in fact, there is a second interest: that of the great whales in the survival of their species or - even short of claims of survival - in their right to live. The whales find their own sustenance in the oceans; by what right do the Inuit expropriate the bodies of the whales to serve as their food? FN254

So far we have not mentioned Doubleday's first argument: that Article 1(2) of the International Covenant on Economic, Social and Cultural Rights prohibits depriving a people of its own means of subsistence. There is force in this contention, even though we argue that the provision should not be taken literally. A literal reading of Article 1(2) would allow, for instance, the continuation of human cannibalism. Or we might imagine a gang of thieves who steal food as they travel from 
town to town; FN255 surely, Article 1(2) would not legitimize this means of [pg60] sustenance. Instead, Article 1(2) should be read to imply a caveat: "so long as other rights are not violated." If we have succeeded in this article in showing that whales have a right to life, Article 1(2) should not be read as depriving them of that right. Nor can the argument be made that because the International Covenant on Economic, Social and Cultural Rights entered into force in 1976, which was before we can specify the beginning of the stage of "entitlement" for whales, no exception for whales can be inferred. Obviously, if whales now have an entitlement to life, they always had it; the only difference is that human recognition of that right has come relatively late in the game.FN256

Yet Article 1(2) cannot be dismissed, because it suggests the one claim that can reasonably and persuasively be made on behalf of the Inuit: that they have been severely disadvantaged by the exploitative commercial whaling practices of the nineteenth and early twentieth centuries, which resulted in endangering the survival of the bowhead species. Absent these practices, the Inuit might at least be able to continue their subsistence whaling without fear of extinguishing the species. To be sure, our "entitlement" argument would protect nonendangered species from whalers — even though the whalers are aborigines and their purpose is subsistence. Yet a weak claim could be advanced that whaling by the Inuit might have been tolerated for some additional years were it not for the invasion of arctic waters by the commercial whalers.

Article 1(2) can therefore be read as saying that the exploitative practices of the commercial whalers (coupled with the inevitable present need to protect the great whales from extinction) deprived the Inuit of their means of subsistence. In a basic sense, those who profited from the commercial whaling now owe the Inuit a reasonable alternative means of subsistence. In short, an obligation has arisen to feed these people if they choose to remain where they are instead of migrating to a place where other food is available or can be grown.

We contend that reparations should be made to the Inuit for the decades of commercial whaling that depleted the bowhead species to the point of endangerment. These reparations should ideally be raised by an environmental tax on all nations whose nationals benefited from that commercial whaling.

An environmental tax is appropriate when the social cost or benefit of a project is not internalized by the persons engaging in that practice. What we label a type I instance of a social cost is exemplified by a polluting factory: if the factory emits sulfur oxides into the atmosphere, or dumps its waste into a river, part of the cost of its operation is passed on to the public as pollution. This "social cost" is not, but should be, internalized by the factory. Thus, society has begun to impose a pollution tax upon such factories, measured by the level of emissions. The factory itself, by installing catalytic converters, may reduce the amount of air pollution it emits and thus reduce the tax. A type II social benefit occurs in the converse situation: the actor internalizes the costs of a social benefit that should be paid for in part by society as a whole. For example, the Brazilian rain forests contribute significantly to replenishing the world's atmospheric oxygen through photogenesis. Although everyone benefits from the maintenance of the rain forest, this benefit is financed by Brazil's renunciation of more favorable economic opportunities, such as cutting down the forest for lumber. Another type II example is the wild game preserve in Kenya. Everyone benefits from the maintenance of endangered species in [pg61] the wild, but Kenya internalizes the cost by forgoing economic exploitation of the preserves. If the rest of the world objects to a Kenyan proposal to allow hunting for sport, for a high fee, in the preserves, the rest of the world should try to remove the incentive for such licensing by paying Kenya a subsidy instead.FN257 
Building on this type II example, we propose that a tax be levied upon those countries whose nationals have benefited directly or indirectly from the unrestrained commercial hunting of bowhead whales, and that the revenues collected be paid to the Inuit as a form of subsidy or reparation for the endangerment of the bowhead species. With these revenues, the Inuit could migrate to places where food is more plentiful, or set up arctic farms, or - at least for a while — simply purchase food supplies. The tax payments could be made over a limited period (for example, twenty years). Reparations in perpetuity would not be fair because, if our presentation of the whales' entitlement to life is persuasive, the Inuit would be legally disabled from hunting whales sooner or later irrespective of the history of exploitative commercial whaling by other nations. Thus, the "social benefit" payments in our type II example should be in reparation for the destruction of the legitimate expectations of the Inuit prior to the whales' final, "entitlement," stage.

\section{CONCLUSION}

Whales are entitled to consideration as moral entities. Whether we can move from moral desirability to legal actuality is a matter of analyzing the process of international customary law. We have contended in this article that the evolution of the opinio juris of nations has encompassed five, and perhaps six, inexorable qualitative stages: free resource, regulation, conservation, protection, preservation and entitlement. We have argued that assigning whales an entitlement to life is the consequence of an emerging humanist right in international law — an example of the merging of the "is" and the "ought" of the law in the process of legitimization. Law is ever striving to "work itself pure," in Lord Mansfield's felicitous phrase. The law that "ought to be" is implicit in the law that "is," because it invests the "is" with a purposive sense of fulfillment and self-realization.FN258 The law that ought to be gives us reason to obey and respect the law that is. Although morality of course shapes the content of law as a matter of historical contingency, the vital consideration is that one cannot fully explain "law" without reference to normative values - what law is striving to achieve. If we merely take a rigid slice-of-time view of international law and argue that, at this very moment, whales either have or lack certain rights, we impose a pseudo-scientific existentiality on international law that does not and cannot capture the richness of what Thomas Franck has called the power of legitimacy in international law.FN259

Thus, while some may question whether we have "reached" the entitlement stage for whales, the very form of the question is misleading. For if the final stage [pg62] of entitlement results from progression through the previous stages, coupled with a sense that further development is inevitable because it is legitimate, an entitlement to life for whales is already implicit, in a fundamental sense, in international law. As the customary law process unfolds, the implicit can be expected to become explicit.FN260

We have argued that the entitlement stage is justified philosophically as well as legally. We have found little justification for current claims of whaling for scientific research, and only a prima facie justification of whaling for aboriginal subsistence needs. However, we predict that - assuming the introduction of certain reparations adjustments - the claim of entitlement of whales will triumph over these counterclaims. Entitlement is finally attained when there is an international consensus that it has been attained. This article has attempted to bring together certain considerations that may contribute to that consensus.

\section{Footnotes}


* Professor D'Amato is a member of the Board of Editors. Mr. Chopra is a staff attorney for the U.S. Environmental Protection Agency in Dallas, Texas. Mr. Chopra's participation in this article was in his private capacity. No official support or endorsement by the United States Government of this article is intended or should be inferred. The authors would like to thank Professor Christopher Stone for his very helpful comments on a draft of this article.

** Numbers in the format [pg21], etc. refer to the pages in the original article.

FN1 Dr. Carl Sagan writes:

Though the search for extraterrestrial intelligence may take a very long time, we could not do better than to start with a program of rehumanization by making friends with the whales and the dolphins. ... They have behaved benignly and in many cases affectionately towards us. We have systematically slaughtered them. C. SAGAN, THE CosmiC CONNECTION 178-80 (1973).

FN2 D. DAY, THE WHALE WAR 152 (1987). Although the whale has a very large body in relation to its brain size, only a minor percentage of the cerebral cortex is directly concerned with control of the body; the whale's cerebral cortex (functioning as memory and conceptual thought) is much larger than a human's. Bunnell, The Evolution of Cetacean Intelligence, in MinD IN THE WATERS 52 (J. McIntyre ed. 1974)[hereinafter McIntyre]. According to Dr. John Lilly, "To think the way we do he [the whale] would need to use about one-sixth of his total brain." J. LiLLy, THE Mind OF THE DolPhin: A NonhumAn INTELLIGENCE 63 (1967). A capacity for humor and playfulness is generally associated with high human intelligence; whales and dolphins, too, conspicuously exhibit playful and humorous behavior. Id. at 58 ("play is a hallmark of intelligence and is indispensable for creativity and flexibility").

FN3 Lilly, A Feeling of Weirdness, in McIntyre, supra note 2, at 71. Dr. Lilly's statement is the best description we have seen about what it is like to be dealing with a possibly superior intelligence.

FN4 See generally J. LILLY, supra note 2.

FN5 Humans, of course, have been unable to develop interspecies communication, except for the most rudimentary signals. See generally J.LiLly, MAN AND DOLPHIN (1961).

FN6 Morgane, The Whale Brain: The Anatomical Basis of Intelligence, in McIntyre, supra note 2, at 84, 91-92. If all brains are "learning machines," as artificial-intelligence researcher Marvin Minsky suggests (M. MinsKy, THE SOCIETY OF MIND 120 (1986)), and these learning machines constitute an efficacious survival mechanism (as the theory of natural selection indicates), the size of whales' brains may indicate a spectacularly efficient survival mechanism. Dr. Lilly speculates: "If a sperm whale, for example, wants to see-hear-feel any past experience, his huge computer [brain] can reprogram it and run it off again. His huge computer gives him a reliving, as if with a three-dimensional sound-color-taste-emotion-re-experiencing motion picture." After thus reviewing the original experience, the whale "can set up the model of the way he would like to run it the next time, reprogram his computer, run it off, and see how well it works." J. LiLLY, supra note 2, at 6364.

FN7 Morgane, supra note 6, at 93 (quoting L. EISELEY, THE LONG LONELINESS). Dr. Lilly asks why sperm whales do not attack humans unprovoked. He suggests that they recognize that "we are the most dangerous animal on this planet" and that if attacked unprovoked, "we would ... wipe 
them off the face of the earth. I believe they recognize that we now have the means to do this. A large fraction of our atomic and nuclear weapons testing is done over and in the Pacific Ocean close to the ocean routes of the big whales." J. LiLLY, supra note 2, at 65.

FN8 Indeed, human hunting and killing of whales may have occurred largely because whales are vulnerable; if whales could have fought back successfully, humans might have learned to respect them and leave them alone. It is one of the darker aspects of human psychology that victims can gain respect by resort to violence. $C f$. W. M. Reisman, The ART Of THE Possible: Diplomatic Alternatives IN THE Middle EAst 44-58 (1970)(discussing Palestinian self-respect resulting from fedayeen terrorism).

FN9 "Whales are killed for chicken feed, cattle fodder, fertilizer, car wax, shoe polish, lipstick, cosmetics, margarine, cat and dog food, and to raise minks and foxes for fur coats." McIntyre, Let Us Act, in McIntyre, supra note 2, at 224, 224.

FN10 Falk, Introduction: Preserving Whales in a World of Sovereign States, 17 DEN. J. INT'L L. \& POL'Y 249, 253 (1989).

FN11 Quoted by D. DAY, supra note 2, at 19 (statement of Prime Minister Fraser).

FN12 See Chopra, Whales: Toward a Developing Right of Survival as Part of an Ecosystem, 17 DEN. J. INT’L L. \& POL’Y 255 (1989).

FN13 Cf. D'Amato, Do We Owe a Duty to Future Generations to Preserve the Global Environment?, 84 AJIL 190, 197-98 (1990).

FN14 We use the term "presentiation" to denote the present instantiation of legitimately realizable expectation. See I. MacNeil, The New Social Contract 60 (1980)(" presentiation . . . is the bringing of the future into the present").

FN15 For a general description of the custom-creating process, see A. D'AMATO, THE CONCEPT OF CUSTOM IN INTERNATIONAL LAW (1971).

FN16 For reasons we give later in this essay, we are not invoking whales as a surrogate for all animals, or claiming that animal rights are logically implicated by human rights. However, we sometimes refer to "cetacean rights" when we see no reason to exclude dolphins and porpoises from a general point made about whales.

FN17 This human-centered way of conceptualizing the duty is challenged in D'Amato, supra note 13. But see Weiss, Our Rights and Obligations to Future Generations for the Environment, 84 AJIL 198 (1990); Gundling, Our Responsibility to Future Generations, id. at 207.

FN18 D. DAY, supra note 2, at 144-47 (quoting David Moody in ECOLOGIST, July 1979).

FN19 A canoa is a 35-foot, narrow, double-ended, sailing/rowing boat usually towed by a motorized support launch.

FN20 Id. at 147. As a mammal, a whale must take oxygen from the air; it cannot "breathe" in the water as does a fish. The naturalist Farley Mowat, observing a dying whale, was amazed to see her 80-ton bulk deliberately going ashore. Why would the whale do that when she could take refuge in the ocean? Someone explained to Mowat that the whale was too sick to swim and must have known that if she stayed in deep water, she would sink and drown. Mowat then heard the whale 
emit a desolate cry — a "muffled, disembodied, and unearthly sound, seeming to come from an immense distance . . . a deep vibration, low-pitched and throbbing, moaning. . . . [I] knew, and know today, that this was her leave-taking." Mowat, The Trapped Whale, in McIntyre, supra note 2, at $13,28$.

FN21 J. Bentham, The Principles of Morals AND LEgislation 311 note (1789). Immanuel Kant accepted the Cartesian position but tried to modify it by moral pragmatism: "Animals are not self-conscious and are there merely as means to an end. That end is man. ... Our duties to animals are merely indirect duties towards humanity. . . . [Man] must practise kindness towards animals, for he who is cruel to animals becomes hard also in his dealings with men." I. KANT, LECTURES ON ETHICs 239-40 (L. Infield trans. 1963).

FN22 Warshall, The Ways of Whales, in McIntyre, supra note 2, at 110, 139-40. The author continues: "The whistle provides a great deal of information: the location of the whistler, the identity of friends, the whereabouts of companions, and the desire to hear a response. Choruses of whistles may be a way to confirm and reconfirm the mood, state of being, or purpose of the group." Id. at 140 .

FN23 Jacobs, The Whale Brain: Input and Behavior, in McIntyre, supra note 2, at 78, 83.

FN24 See generally T. Regan, The CASE FOR Animal Rights (1983); see also P. TAYLOR, ReSPECT FOR NATURE: A THEORY OF ENVIRONMENTAL ETHICS 219-40 (1986); R. ATTFIELD, THE ETHICS OF ENVIRONMENTAL CONCERN 140-62 (1983).

FN25 See supra text at notes 1-2.

FN26 N. ChOMsKy, CARTESiAn Linguistics 6 (1966)(quoting The Philosophy OF Descartes 284-87 (Torrey ed. 1892)). The Cartesians who are still among us deny that chimpanzees use "language" by increasingly restricting their definition of what "language" is. Thus, as chimpanzees are taught to use sign language, and communicate to us their own spontaneous combinations of thoughts, some Cartesian doubters argue that the only language that counts is speech through vocal cords! Others argue that until chimpanzees display a knowledge of grammatical syntax, they are not using language. For a skeptical view, see H. TERRACE, Nim: A ChimpanzeE Who LEARNED SIGN LANGUAGE (1979).

FN27 Quoted by L. Rosenfield, From BeAst-Machine to MAN-MACHine 54 (1968).

FN28 L. Wittgenstein, Philosophical InVEstigations §§ 293-304 (1953).

FN29 See L. Wittgenstein, The Blue And Brown Books 44-54 (1958); 1 L. Wittgenstein, Remarks On The Philosophy Of Psychology §§ 137-54 (1980).

FN30 Since whales were already well equipped for survival in the oceans when they first appeared 50 million years ago, there is no clear Darwinian reason that their brains grew to the large size attained 30 million years ago. Dr. Bunnell speculates, instead, that the most likely explanation "seems to be social and sexual selection - that is, the society of the whales - since the sea does not seem to be a demanding enough habitat to require such an increase in brain size." Using dolphins as an example, he continues:

With echolocation, ... . a dolphin gets a three-dimensional, detailed cognition of the physical and emotional state of another dolphin's entire body and it appears that the eroticism of dolphins is related to group organization and hierarchy as well as reproductive functions.... In short, the 
brains of whales and dolphins may have continued to enlarge as an adaptation to intelligent societies....

Bunnell, supra note 2, at 65.

FN31 See, e.g., J. LiLly, supra note 5; B. GILBERT, How ANimALs CoMmuniCATE (1966).

FN32 Quoted by R. W. Clark, The Survival Of Charles Darwin: A Biography Of A Man AND AN IDEA 76 (1984).

FN33 $C f$. P. Singer, ANimal Liberation: A New Ethics FOR OUR TrEatMENT Of ANimAls 223-58 (1975).

FN34 What about the right to vote? The right to shelter? The rights of other animals? Of plants? People who ask these kinds of questions may not be sincerely interested in the answers we might offer. Our general answer is that a powerful case can be made on behalf of the entitlement of whales to a right to life. We make no claim that the entitlements asserted in this article should apply exclusively to whales, of that these are the only entitlements that should apply to whales. We make a minimal case; it is compatible with reasoned argument for extensions in either of these directions. In addition, we are in complete accord with the limited arguments made on behalf of elephants by Professor Michael Glennon, Has International Law Failed the Elephant?, 84 AJIL 1 (1990).

That much said, a general case can be made on behalf of all sentient animals, including whales, for a right not to be inflicted with unnecessary or arbitrary pain. There is a substantial history of anticruelty laws regarding animals that suggests that the majority of the population believes that it is morally wrong to torture or conflict unnecessary pain upon animals. See generally E. LEAVITT, ANIMALS AND THEIR LEGAL Rights (2d ed. 1970). This book provides a survey of American laws from 1641 to 1970 and of the laws of many other countries. See also B. RoLLin, ANIMAL Rights AND HUMAN MORALITY 77 (1981)

FN35 D. Hume, ENQUiRIEs CONCERNING HuMAN UnDERSTANDING AND CONCERNING THE PRINCIPLES OF MORALS 190-91 (Selby-Bigge \& Nidditch 3d ed. 1975) (1777).

FN36 Buchanan, Justice as Reciprocity versus Subject-Centered Justice, 19 PHIL. \& PuB. AfF. 227, 230 (1990).

FN37 Of course, it is impossible ever to know for sure that we will be incurring a net cost. The question is as old as Glaucon's challenge to Socrates in Plato's Republic. For an illuminating discussion, see R. NOZICK, PHILOSOPHICAL EXPLANATIONS 403-570 (1981). For a brief discussion of deontological morality, see D'Amato \& Eberle, Three Models of Legal Ethics, 27 ST. LoUIS U.L.J. 761, 772-73 (1983).

FN38 Indeed, all "legal materials" exhibit this synthesis; in international law, it is more explicit because of the relative lack, compared to domestic legal systems, of authoritative codification institutions. See A. D'AMATO, JuRISPRUDENCE: A DESCRIPTIVE AND NORMATIVE ANALYSIS OF LAW 180-227 (1984); T. FrAnCK, THE POWER OF LEGITIMACY AMONG NATIONS 3-26 (1990).

FN39 One writer has characterized whaling as the "most infamous example of human mismanagement of the earth's natural resources." S. LYSTER, INTERNATIONAL WILDLIFE LAW 17 (1985). 
FN40 Id. at 17; 1 P. BiRnie, InTERNATIONAL REGULATION OF WHALING 66 (1985). For histories of whaling, see generally G. SMALl, The Blue Whale (1971); I. SANDERSOn, Follow the Whale (1956); M. Raestal, La Chasse A La Baleine En Mer Libre (1928); A. StarbucK, History Of The American Whale Fishery (1878); E. Slipjer, Whales (1962); R. Robertson, OF Whales AND Men (1954); C. Ashley, The YANKeE Whaler (1962); Jessup, L'Exploration des richesses de la mer, 29 RECUEIL DES COURS 401, 481-502 (1929 IV). The most recent comprehensive work is J. TONNESSEn \& A. JoHnson, THE History OF MODERn WHALing (1982).

FN41 The right whale is a major species of intermediate size-somewhat more than half the size of the largest species, the blue whale.

FN42 1 P. BIRNIE, supra note 40, at 17; N. MACKInTOsh, The StOcK OF Whales 146 (1965).

FN43 The third largest whale of the major species.

FN44 E. SliPJER, supra note 40, at 22; 1 P. BIRNIE, supra note 40, at 68. See generally G. JACKSON, THE BRITISH WHALING TRADE 3-156 (1978).

FN45 E. SLIPJER, supra note 40, at 25; 1 P. BIRNIE,, supra note 40, at 69.

FN46 S. LYSTER, supra note 39, at 17; 1 P. BIRNIE,, supra note 40, at 69 n.10

FN47 Leonard, Recent Negotiations Toward the International Regulation of Whaling, 35 AJIL 91 (1941); E. SLIPJER, Geneva Convention 40, at 31-32; P. BoCK, A STUDY In INTERNATIONAL Regulation: The CASE OF Whaling 66 (1966) (unpublished thesis, New York University, obtainable from University Microfilms Inc., Ann Arbor, MI); J. TONNESSEN \& A. Johnson, supra note 40, at 23-33; 1 P. BIRNIE, supra note 40, at 71.

FN48 1 P. BIRNIE,, supra note 40, at 72.

FN49 Within a year, seven floating factories were operating. By 1910, two land factories and 14 factory ships were operating. J. TONNESSEN \& A. JoHnson, supra note 40, at 178-82.

FN50 Leonard, supra note 47, at 91, 96.

FN51 E. SLIPJER, supra note 40, at 33-34; 1 P. BIRNIE,, supra note 40, at 73. Earlier catches were primarily of humpback whales; 5,755 were killed in 1911-1912. This overexploitation led to scarcity and in the later years the catch of humpbacks was drastically reduced; blue whales, however, were harvested in the thousands.

FN52 1 P. BIRNIE, supra note 40, at 73 n.26.

FN53. Id. at 74.

FN54 D. JOHNSTON, THE INTERNATIONAL LAW OF FISHERIES 398 (1965).

FN55 Conservation is a more acute problem for whales than for fish, owing to their long life cycle. Whales give birth to live calves and suckle their young. Female sperm whales take about 7-13 years to mature, while males take up to 20 years, and breeding often does not begin until the age of 30. C. LOCKYER, Estimates of GROWTH AND ENERGy BudGETS FOR THE Whales 5, UN Doc. FAO/ACMMR/MM/SC 38 (1976); R. GAMBLE, CHANGES OBSERVED IN PREGNANCY RATE AND Age at SeXual Maturity of Some Baleen Whales in the Antarctic 11-12, UN Doc. FAO/ACMMR/MM/SC 37 (1976); R. HARRISON \& J. KING, MARINE MAMMALS 91 (1965); E. SLIPJER supra note 40, at 388-90; 1 P. BIRNIE, supra note 40, at 23. Baleen (or toothless) whales are 
thought to follow the same pattern, but under reduced population conditions are able to reproduce at the age of 5-6 years.

FN56 D. JOHnSTON, supra note 54, at 398-99.

FN57 Convention for the Regulation of Whaling, Sept. 24, 1931, 49 Stat. 3079, TS No. 880, 155 LNTS 349.

FN58 The Convention was negotiated by a subcommittee of the Economic Committee of the League. See LEONARD, supra note 47, at 98-100; D. Johnston, supra note 54, at 399; C. ColOMBOS, THE INTERNATIONAL LAW OF THE SEA 380 n.3 (1962). Japan, the USSR, Argentina and Chile were among the whaling states that did not ratify the Convention. For a detailed account, see Vallance, The International Convention for Regulation of Whaling and the Act of Congress Giving Effect to Its Provisions, 31 AJIL 112, 112-19 (1937).

FN59 Convention for the Regulation of Whaling, supra note 57, Art. 9.

FN60 Id., Art. 1.

FN61 Id., Art. 8.

FN62 Id., Art. 5.

FN63 Id., Art. 4.

FN64 See Leonard, supra note 47, at 100.

FN65 D. JOHnSTOn, supra note 54, at 399; J. TOMASEVIC, InTERNATIONAL AgrEEMENTS ON THE CONSERVATION OF MARINE RESOURCES 282-84 (1943).

FN66 D. Johnston, supra note 54, at 399; J. TOMASEVIC, supra note 65, at 285; 1 P. BIRNIE, supra note 40, at 120-24. A 1936 agreement between the United Kingdom and Norway, negotiated after both countries joined the 1931 Convention for the Regulation of Whaling, was designed to further strengthen its protectionist measures. For the first time, an international penalty was provided. In addition, the regulated area was increased, and the hunting season shortened. A sanctuary area was also introduced. See 10 InTERnATIOnAL WhaLing STATISTICS 1 (1937). Since the agreement was between only two states and since many major whaling countries such as Japan, the USSR, and Germany were reluctant even to joined the 1931 Convention, the new restrictions between Britain and Norway did not prove to be effective.

FN67 D. Johnston, supra note 54, at 400; 1 P. BIRNIE, supra note 40, at 125 . According to Johnston, nine states participated in the negotiations, but Japan refused. Birnie refers to ten states, of which three (Portugal, Canada and South Africa) sent only observers. Other states that participated in the negotiations were Argentina, Australia, Germany, the Irish Free State, New Zealand, the United Kingdom and the United States. For other accounts, see Leonard, supra note 47, at 10102.

FN68 June 8, 1937, 52 Stat. 1460, TS No. 933, 190 LNTS 79.

FN69 Right whales were already protected under the 1931 Convention; in addition, the 1937 Agreement, in Article 4, prohibited the taking of gray whales.

FN70 1 P. BIRNIE, supra note 40, at 125; D. JOHNSTON, supra note 54, at 400. 
FN71 Protocol on Regulation of Whaling, June 24, 1938, 53 Stat. 1794, TS No. 944, 196 LNTS 131. This Protocol was hardly an improvement, although it provided for a new sanctuary in waters that were not being fished (Art. 2). So far as the Antarctic catch was concerned, this measure did nothing.

FN72 D. JOHNSTON, supra note 54, at 400.

FN73 See Taylor \& Ward, Chickens, Whales, and Lumpy Goods: Alternative Models of PublicGoods Provision, 30 POL. STUD. 350, 359-60 (1982).

FN74 1 P. BIRNIE, supra note 40, at 126.

FN75 1938 Protocol, supra note 71, Art. 1; 1 P. BIRNIE, supra note 40, at 127.

FN76 1 P. BIRNIE, supra note 40, at 128; D. JOHNSTON,, supra note 54, at 400; Leonard, supra note 47, at 105. See U.S. Department of State Press Release, July 5, 1939.

FN77 1 P. BIRNIE, supra note 40, at 129-30.

FN78 Nov. 26, 1945, 61 Stat. 1213, TIAS No. 1597, 11 UNTS 43. Signatories to the Protocol were Australia, Canada, Denmark, France, Mexico, the Netherlands, New Zealand, Norway, the Union of South Africa, the United Kingdom and the United States. The Soviet Union acceded later. For the Protocol of Feb. 7, 1944, see 1946 Gr. Brit. TS No. 61 (Cmd. 6990); and for the Protocol of Dec. 2, 1946, extending the 1945 Protocol, see 62 Stat. 1577, TIAS No. 1708, 161 UNTS 361.

FN79 1945 Protocol, supra note 78, Art. 4(1).

FN80 Id., Art. 4(2).

FN81 Proclamation on the continental Shelf, 10 Fed. Reg. 12,303, 12,304 (1945); Watt, First Steps in the Enclosure of the Oceans: The Origins of Truman's Proclamation on the Resources of the continental Shelf, 28 MARINE POL'y 211 (1979). See also Jessup, The Pacific Coast Fisheries, 33 AJIL 129 (1939); Bishop, International Law Commission Draft Articles on Fisheries, 50 AJIL 627 (1956); Bishop, Exercise of Jurisdiction for Special Purposes in High Seas Areas Beyond Outer Limit of Territorial Waters, 99 CONG. REC. 2493 (1953); M. S. McDougAL \& W. Burke, The PuBLIC ORDER OF THE OCEANS 630-33 (1962).

FN82 See Hollick, The Origins of 200-Mile Offshore Zones, 71 AJIL 494 (1977). Chile established the first 50-mile zone in 1947, to protect offshore whaling operations. Ecuador and Peru followed in 1951 and 1947, respectively, with declarations extending their coastal zones. In 1952 Chile, Ecuador and Peru adopted the Declaration Maritime Zones asserting their sovereignty, up to 200 miles, over the sea, the sea floor and its subsoil. The basis of these claims has been criticized by M. S. McDougAL \& W. BuRKE, supra note 81, at 453-65; and D. JOHnSTON, supra note 54, at 337. See generally F. V. GARCIA-AMADOR, THE EXPLOITATION AND CONSERVATION OF THE RESOURCES OF THE SEA (1968).

FN83 Dec. 2, 1946, 62 Stat. 1716, TIAS No. 1849, 161 UNTS 72. The Convention was amended in 1956 to incorporate regulations on methods of inspection, and to extend the definition of "whale catchers" to cover aircraft and helicopters. This amendment has since allowed the IWC to revise its schedule annually. Protocol of Nov. 19, 1956, 10 UST 952, TIAS No. 4228, 338 UNTS 366. 
FN84 1 P. BIRNIE, supra note 40, at 265. On freedom of the seas, see D. JoHnston, supra note 54, at 157-72, 303-08; on territorial sea, see id. at 173-252; H. GROTIUS, DE JURE BELLi AC PACIS LiBri Tres, bk. 2, ch. 3, pt. 15 (Carnegie ed., F. Kelsey trans. 1925) (1625); H. GrotiUs, MARE LiBERUM 37 (Magoffin trans. 1916) (1608); J. SELDEN, MARE ClAUSUM, bk. 1, at 2 (Nedham trans. 1652) (1636); and the final response of Grotius, the pamphlet DEFEnSE OF CHAPTER 5 OF MARE LiBERUM, in 7 BiBliotheCA VisSERIANA 154 (Wright trans. 1928). For an account of the GrotiusSelden controversy, see J. L. HARgrove \& A. D'Amato, Environment And The LAw Of The SEA (1974). See also T. Fulton, The Sovereignty Of The SeAs 366-77 (1911); P. T. Fenn, The OrIGiN Of The Right Of Fisheries In TERRITORIAL WATERS 150-152 (1926); Hudson, The First Conference for the Codification of International Law, 24 AJIL 447, 456 (1930); Walker, Territorial Waters: The Cannon-Shot Rule, 22 Brit. Y.B. Int'l 210 (1945); Kent, The Historical Origins of the Three-Mile Limit, 48 AJIL 537 (1954); P. JESSUP, LAW OF TERRITORIAL WATERS AND MARITIME JURISDICTION 73 (1927); S. RIESENFELD, PROTECTION OF COASTAL FISHERIES UNDER INTERNATIONAL LAW 279 (1942).

FN85 Preamble, ICRW, supra note 83. See also Article I(2), which describes the ICRW as applying to "factory ships, land stations, and whale catchers under the jurisdiction of the contracting Governments, and to all waters in which whaling is prosecuted by such factory ships, land stations, and whale catchers."

FN86 Id., Preamble.

FN87 See generally Smith, The International Whaling Commission: An Analysis of the Past and Reflections on the Future, 16 NAT. RESOURCES LAW 543 (1984).

FN88 ICRW, supra note 83, Art. V.

FN89 In 1959 the IWC meeting was attended by 15 member states. The Netherlands, Norway and Japan threatened to withdraw because of disagreements over quota allocations. See INTERNATIONAL WhALING COMMISSION REPORT, App. I, at 8-9 (1960) [hereinafter IWC/REPORT/year of publication]; 1 P. BIRNIE, supra note 40, at 247. Brazil and Panama were absent in 1959. The Netherlands returned in 1962. See id. at 304 n.4.

FN90 IWC/7TH REPORT/1956, at 5, paras. 16-18.

FN91 IWC/10TH REPORT/1959, at 7, para. 15.

FN92 Agreement Relating to the Organization of Permanent Commission of the Conference on Exploitation and Conservation of the Marine Resources of the South Pacific, Aug. 18, 1952, 1006 UNTS 331. For a detailed account of the PCSP, see M. SAVIANI, REPORT ON INTERNATIONAL AND National Legislation for The Conservation of MARine MAmmals 25-35 (FAO Fisheries Circular No. 326), UN Doc. FIRD/C/326 (1974); 1 P. BIRNIE, supra note 40, at 230, 269-73.

FN93 1 P. BIRNIE, supra note 40, at 269.

FN94 Id.

FN95 At present (1990), Japan is the sole nation, joined only by various aboriginal claimants, asserting that some whaling is necessary for consumption.

FN96 Apr. 29, 1958, 17 UST 138, TIAS No. 5969, 559 UNTS 285 (entered into force Mar. 20, 1966). 
FN97 The first resolution, Resolution on International Fishery Conservation Convention, states, in part:

Taking note of the opinion of the International Technical Conference on the Conservation of the Living Resources of the Sea, held in Rome in April/May 1955, as expressed in paragraph 43 of its report, as to the efficacy of international conservation organizations in furthering the conservation of the living resources of the sea,

Believing that such organizations are valuable instruments for the co-ordination of scientific effort upon the problem of fisheries and for the making of agreements upon conservation measures.

\section{Recommends:}

1. That States concerned should co-operate in establishing the necessary conservation regime through the medium of such organizations covering particular areas of the high seas or species of living marine resources and conforming in other respects with the recommendations contained in the report of the Conference. ...

2 United Nations Conference On The Law Of The Sea, OfFicial Records 144, UN Doc. A/CONF. 13/38, UN Sales No. 58 V.4, Vol. II (1958) [hereinafter OfFICIAL RECORDS]. The second resolution, Co-operation in conservation measures, state:

Taking note of the opinion of the International Technical Conference on the Conservation of the Living Resources of the Sea, held in Rome in April/May 1955, as reported in paragraphs 43 (a), 54 and other of its report, that any effective conservation management system must have the participation of all States engaged in substantial exploitation of the stock or stocks of living marine organisms which are the object of the conservation management system or having a special interest in the conservation of that stock or stocks.

Recommends to the coastal States that, in the cases where a stock or stocks of fish or other living marine resources inhabit both the fishing areas under their jurisdiction and areas of the adjacent high seas, they should co-operate with such international conservation organizations as may be re-

sponsible for the development and application of conservation measures in the adjacent high seas, in the adoption and enforcement, as far as practicable, of the necessary conservation measures on fishing areas under their jurisdiction.

Id.

FN98 See R. BeVerton \& S. Holt, On the Dynamics of Exploited Fish Populations 37273 (1957). See also D. Johnston, supra note 54, at 51 (quoting Gordon, Obstacles to Agreement on Control in Fishing Industry, in THE ECONOMICS OF FISHERIES (Proceedings of Round Table held under joint auspices of the FAO and the International Economic Association) (R. Turney \& J. Wiesman eds. 1957)).

FN99 D. JOHNSTON, supra note 54, at 51 (quoting Gordon, supra note 98).

FN100 Res. V. Humane Killing of Marine Life, 2 OfFICIAL RECORDS, supra note 97, at 144.

FN101 Dec. 1, 1959, 12 UST 794, TIAS No. 4780, 402 UNTS 71, reprinted in 1 W. BuSH, ANTARCTICA AND INTERNATIONAL LAW: A COLLECTION OF INTER-STATE AND NATIONAL DOCUMENTS 46 (1982).

FN102 Antarctic Treaty, supra note 101, preamble. The Treaty was preceded by the creation of the Scientific committee of Antarctic Research (SCAR). 1 W. BUSH, supra note 101, at 5, SCAR is 
the Scientific Committee of the International Council of Scientific Unions, a much larger organization covering all areas of the sciences. It is charged with furthering the coordination of scientific activity in Antarctica, with a view to framing a scientific program of circumpolar scope and significance.

Article IX (1)(f) of the Antarctic Treaty refers to the "preservation and conservation of living resources in the Antarctic." Other measures to conserve Antarctic flora and fauna have been taken since 1959. See, e.g., convention for the Conservation of Antarctic Seals, June 1, 1972, 29 UST 441, TIAS No. 8826.

FN103 The Preamble to the Convention, supra note 102, refers to the need "to maintain a satisfactory balance with the ecological system."

FN104 ATCP Recommendation III-VIII, 1 W. BUSH, supra note 101, at 146.

FN105 Although the Antarctic Treaty evaded the issue of direct regulation of whales, which falls under the IWC's jurisdiction, the ATCP group has consistently striven to preserve the ecosystem, and through this approach, individual habitats. For the species to survive, whales must be left alone and given the opportunity to replenish their stock in their natural habitat, and their ecosystem must be left undisturbed. The Antarctic Treaty established a sound international regime for the preservation of the whole ecosystem, which will permit individual species to grow undisturbed by too much adverse effect from human activity. Gulland, The Antarctic Treaty System As a Resource Management Mechanism, in AnTARCTIC TrEATy Regime 116, 116-24 (G. Triggs ed. 1987).

FN106 IWC/15TH REPORT/1963, at 20-21, para. 18, and Appendix to Chairman's Report at 23-26.

FN107 1 P. BIRNIE, supra note 40, at 273-73. The fisheries commissions were (1) Permanent Commission of the Conference on the Use and Conservation of the Maritime Resources of the South Pacific (PCSP), supra note 92; (2) International Convention for the North West Atlantic Fisheries, Feb. 8, 1949, 157 UNTS 157; (3) Convention Relating to the Establishment of An International Commission for the Scientific Investigation of Tuna, Jan. 25, 1949, 99 UNTS 4: (4) International Convention for the High Seas Fisheries of the North Pacific Ocean, May 9, 1952, 4 UST 380, TIAS No. 2786, 205 UNTS 65; (5) Convention Concerning the High Seas Fisheries of the Northwest Pacific Ocean, May 14, 1956, reprinted in 53 AJIL 763 (1959); (6) Agreement Between Norway and the USSR on Measures for Regulation of the Catch and Conserving Stocks of Seals in the North-Eastern Part of the Atlantic Ocean, Nov. 22, 1957, 309 UNTS 269; (7) North-East Atlantic Fisheries Convention, Jan. 24, 1959, 486 UNTS 158; (8) Convention for Cooperation in the Execution of Fisheries, Oceanological and Limnological Research in the Western Pacific (1956), INTERNATIONAL Fisheries Bodies 18 (FAO Fisheries Technical Paper No. 64, 1966); (9) Convention Concerning Fishing in the Black Sea, July 7, 1959, 377 UNTS 203; (10) Convention for the Preservation of the Halibut Fishery of the Northern Pacific Ocean, Mar. 2, 1953, 222 UNTS 78; (11) Protocol between the United States and Canada to the Convention for the Protection, Preservation and Extension of the Sockeye Salmon Fisheries in the Fraser River System, Dec. 28, 19568 UST 1057, TIAS No. 3867, 290 UNTS 103; (12) Interim Convention on Conservation of North Pacific Fur Seals, Feb. 9, 1957, 314 UNTS 105.

FN108 1 P. BIRNIE, supra note 40, at 270-71.

FN109 IWC/22D REPORT/1970, at 20, para. 3 
FN110 IWC/23D REPORT/1971, at 22, para. 17, and Chairman's Report at 18-19.

FN111 IWC/24TH REPORT/1972, at 13-14, and Chairman's Report at 21.

FN112 GA Res. 2398 (XXIII) (Dec. 6, 1968); see also 1 P. BIRNIE, supra note 40, at 365.

FN113 1 P. BIRNIE, supra note 40, at 365. The resolution was passed in committee by a vote of 52-3, and in the plenary by 53-0, with 12 abstentions including Japan.

FN114 Stockholm Declaration on the Human Environment, Principle 4, UN Doc. A/CONF.48/14/Rev.1, reprinted in 11 ILM 1416 (1972) [hereinafter Stockholm Declaration]. Some of the 26 principles that are also of importance to whales include states' responsibility to adopt an integrated and coordinated approach to development planning so as to achieve more rational resource management (Principle 13), states' responsibility not to cause damage to the environment of other states or of areas beyond the limits of their national jurisdiction (Principle 21), and the duty of states to ensure the effectiveness of international organizations set up to protect and improve the environment (Principle 25).

FN115 Stockholm Action Plan, Recommendations 33, UN Doc. A/CONF.48/14/Rev.1 (1972), reprinted in 11 ILM at 1421.

FN116 1 P. BIRNIE, supra note 40, at 422; IWC/24TH REPORT/1972, Report of the Scientific Committee, at 28.

FN117 Gulland, The Management of Antarctic Whaling Resources, 31 JouRNAL Du CONSEIL InTERnATIONAL Pour L'EXPlOITATION DE LA MER 330 (1968) [hereinafter Gulland, Whaling]; Gulland, The Management Regime for Living Resources, in THE ANTARCTIC LEGAL REGIME 222 (C. Joyner \& S. Chopra eds. 1988); 1 P. BIRNIE, supra note 40, at 407.

FN118 1 P. BIRNIE, supra note 40, at 407; Gulland, Whaling,, supra note 117, at 334.

FN119 U.S. Dep't of State, U.S. Delegation Press Release No. HE/13/72, at 1-2 (June 9, 1972).

FN120 1 P. BIRNIE, supra note 40, at 408.

FN121 Id. at 432-34. It should be noted that the Scientific Committee may have felt that its own existence would be jeopardized by a blanket moratorium.

FN122 IWC/25TH REPORT/1973, Verbatim Record, at 9 (Statement by Mr. Dasman, IUCN).

FN123 Id. at 23 (Statement by Mr. White, U.S.)

FN124 IWC/26TH REPORT/1974, App. I at 25, para. 9. All 15 nations attended this meeting.

FN125 IWC/26TH REPORT/1974, at 30, para. 16.

FN126 Id., para. 17.

FN127 The meeting in 1977 saw the return of the Netherlands to the IWC. It was attended by all 17 members, the largest number in many years. IWC/29TH REPORT/1977, at 14-15. For the first time, scientifically qualified observers were permitted to attend the meetings of the Scientific Committee. Professor Birnie says that the media were allowed to attend the opening and closing proceedings of the plenary session as a public-relations initiative by the IWC to improve its image in the face of growing international criticism. 1 P. BIRNIE, supra note 40, at 475-76. 
FN128 About 70 states by then had proclaimed an exclusive 200-mile fisheries zone. $1 \mathrm{P}$. BIRNIE, supra note 40, at 478.

FN129 IWC/29TH REPORT/1977, at 22; see also Art. 54, Revised Single Negotiating Text, UN Doc. A/CONF.62/WP.8/Rev.1, pt. I, 5 Third United NATIONS CONFERENCE On The LAW Of The SEA, OfFICIAL RECORDS 125, UN Sales No. E.76.V.8 (1976).

FN130 Convention on International Trade in Endangered Species of Wild Fauna and Flora, Mar. 6, 1973, 27 UST 1087, TIAS No. 8249, 993 UNTS 243. CITES will be covered in detail later in this paper. For description of CITES and how it operates, see S. LYSTER, supra note 39, at 239; Chopra, Introduction: CITES, 5 B.U.J. INT'L L. 225 (1987).

FN131 IWC/29TH REPORT/1977, App. B.

FN132 1 P. BIRNIE, supra note 40, at 479-80 n.58.

FN133 See supra text at note 98.

FN134 The Scientific Committee recommended that "from a biological point of view the only safe course is for the kill of bowhead whales from the Bering Sea stock to be zero." IWC/31st Mtg./1979, Chairman's Report, para. 12.

FN135 Adams v. Vance, 8 Envtl. L. Rep. 20, 160 (D.C. Cir.; order filed Oct. 24, 1977, opinion filed Jan. 17, 1978). For detailed discussion of the 31st meeting, see generally Birnie \& Sandbrook, IWC - Increasing Complexities, 3 MARINE POL'Y 69 (1979).

FN136 The bowhead whaling exception continues to tarnish the reputation of the United States. In 1980 the United States claimed that the catch limit should be 18 landed or 26 struck, and a majority of the members of the IWC supported this claim. Despite the severely endangered status of the bowhead, by 1987 the United States was requesting an increase in the catch limit to 32 struck for that year and 35 struck for 1988; both of these requests were adopted by the IWC. Sumi, The "Whale War" Between Japan and the United States: Problems and Prospects, 17 DEN. J. INT'L L. \& POL'Y 317, 327 (1989).

FN137 1 P. BIRNIE, supra note 40, at 499.

FN138 For a detailed report on this meeting, see Birnie, 31st Meeting of the International Whaling Commission London, U.K., 4 MARINE POL'Y 72 (1980). There were six new members, four of which were whaling states. Twenty observer states and thirty nongovernmental organizations were added as well.

FN139 IWC/31st Mtg./1979/OS (opening statement [OS] of the United States).

FN140 IWC/31st Mtg./1979/OS (Australia) (emphasis added).

FN141 Id.

FN142 IWC/31st Mtg./1979/OS (New Zealand).

FN143 IWC/31st Mtg./1979, at 26.

FN144 1 P. BIRNIE, supra note 40, at 505.

FN145 See note 130 supra. For additional discussion of CITES, see 1 P. BIRNIE, supra note 40, at 394-98; 2 id. at 576-77; H. MitCHELL, HISTORY OF CITES (1977). For various aspects of its application, see Symposium: CITES, 5 B.U.J. INT'L L. 225 (1987); D. FAVRE, INTERNATIONAL 
Trade In Endangered Species: A Guide To CITES (1989). CITES originated in Resolution V of the Eighth General Assembly of the IUCN in 1963. 1 P. BIRNIE, supra, at 391; S. Lyster, supra note 39, at 239. The resolution called for "an international convention on regulation of export, transit and import of rare or threatened wildlife species or their derivative products." This principle was endorsed by the Stockholm Conference, which recommended that a conference be convened to adopt such a convention. See Stockholm Action Plan, supra note 115, Rec. 99(3).

FN146 S. Lyster, supra note 39, at 243-46; 1 P. BIRNIE, supra note 40, at 393.

FN147 1 CITES, Proc., Apps. I \& II (listings on p. 49) (1976); see also 1 P. BIRNIE, supra note 40, at 394.

FN148 1 P. BIRNIE, supra note 40, at 394.

FN149 2 CITES, PRoc. 1136 (1979); for detailed proposals, see id. at 949-1018.

FN150 Id. at 43; see also statement by CITES Secretary-General to 31st meeting of the IWC (1979), IWC/31st Mtg./1979/OS. CITES also recommended that nonparties be encouraged to adhere to the ICRW.

FN151 3 CITES, PRoc. 1304 (1981). For details of various proposals and reports, see id. at 1196-1286; IWC/32d Mtg./1980, Ann. D at 4, and Ann. F at 14; 1 P. BIRNIE, supra note 40, at 576.

FN152 For a detailed account of this meeting, see generally Birnie, IWC Bargaining and Compromise, 5 MARINE POL'Y 79 (1981).

FN153 IWC/32d Mtg./1980/OS (Australia).

FN154 2 P. BIRNIE, supra note 40, at 602. The United States was caught between its advocacy of a moratorium on commercial whaling and its support of aboriginal whaling of the bowhead whale. The United States representative indicated that if the take of bowheads continued at 1979 levels, the species would become endangered. Although the United States sought short-term quotas to satisfy aboriginal needs, its representative promised to seek aboriginal support for alternatives and an eventual phaseout of aboriginal whaling. See id. at 604-05.

FN155 Id. at 602-03. The vote on the U.S. proposal was 13 in favor and 9 against (Canada, Chile, Iceland, Japan, the Republic of Korea, Peru, South Africa, Spain, the USSR), with 2 abstentions (Brazil, Norway). The vote on the latter proposal was 14 in favor and 6 against (Canada, Chile, Iceland, Japan, the Republic of Korea, the USSR), with 4 abstentions (Norway, Peru, Spain, South Africa).

The 1980 meeting was also notable for recognizing ecosystem effects; a resolution was passed urging member states to take measures to prevent degradation of the marine environment that might adversely affect whale populations. Id. at 607; IWC/32d Mtg./1980, Chairman's Report, App. 10 at 32.

FN156 IWC/33d Mtg./1981, Chairman's Report at 17-42. For a summary of this meeting, see generally Birnie, IWC - A New Era, 6 MARINE POL'Y 74 (1982). There were eight new members: China, Costa Rica, Dominica, India, Jamaica, St. Lucia, St. Vincent and the Grenadines, and Uruguay. These were primarily states favoring conservation. Canada was represented only by an observer; it had withdrawn because of internal political struggles over the IWC.

FN157 IWC/33d Mtg./1981/OS (Costa Rica and India). 
FN158 The vote was 16 for and 8 against, with 3 abstentions. See 2 P. BIRNIE, supra note 40, at 609.

FN159 The vote was 15 for and 8 against, with 4 abstentions. Id. at 610.

FN160 By France. The vote was 13 for and 9 against, with 5 abstentions. Id.

FN161 By Australia. The vote was 15 for and 8 against, with 4 abstentions. Id. at 610-11. Australia pointedly concluded that the industry was jeopardizing an international resource heritage.

FN162 The vote was 24 for and 1 against (Japan), with 3 abstentions (China, Iceland, the USSR). Id. at 610 .

FN163 Opened for signature Dec. 10, 1982, UN Doc. A/CONF. 62/122, reprinted in UNITED Nations, Official TeXt Of The United Nations Convention On The Law Of The Sea With ANNEXES AND INDEX, UN Sales No. E.83.V.5 (1983).

FN164 See D'Amato, An Alternative to the Law of the Sea Convention, 77 AJIL 281 (1983). As of 1990, 125 nations have signed the Convention, 23 have ratified without qualifications, and 14 have ratified with qualifications. For a listing of the states, see B. WESTON, R. FALK \& A. D'AMATO, BASIC DOCUMENTS In INTERNATIONAL LAW AND WORLD ORDER 946-47 (2d ed. 1990).

FN165 This provision is extended to the high seas by Article 120, which says that "Article 65 also applies to the conservation and management of marine mammals on the high seas."

FN166 See generally D. Day, supra note 2.

FN167 Although Dominica and Jamaica were absent, eight new members were present: Antigua, Belize, Egypt, Kenya, Monaco, the Philippines, the Federal Republic of Germany and Senegal. For a detailed account of this meeting, see generally Birnie, Count down to Zero, 7 MARINE POL'Y 68 (1983); IWC/34th Mtg./1982, Chairman's Report at 17-42.

FN168 IWC/34th Mtg./1982/OS (the Seychelles).

FN169 See amended para. 10 of the ICRW schedule. For the full text of the moratorium, see 2 P. BIRNIE, supra note 40, at 713. The IWC also granted Japan's request for a two-year respite from its earlier moratorium on sperm whaling.

FN170 Voting in favor were Antigua, Australia, Belize, Costa Rica, Denmark, Egypt, France, the Federal Republic of Germany, India, Kenya, Mexico, New Zealand, Oman, St. Lucia, St. Vincent, Senegal, the Seychelles, Spain, Sweden, the United Kingdom, the United States; voting against were Brazil, Iceland, Japan, the Republic of Korea, Norway, Peru, the USSR; and Chile, China, the Philippines and South Africa abstained.

FN171 ICRW, supra note 83.

FN172 See Doubleday, Aboriginal Subsistence Whaling: The Right of Inuit to Hunt Whales and Implications for International Environmental Law, 17 DEN. J. INT'L L. \& POL'Y 373 (1989).

FN173 Art. 1, Council Regulation No. 348/81, 24 O.J. Eur. CoMM. (No. L 39) 1 (1981).

FN174 Art. 235, Treaty Establishing the European Economic Community, Mar. 25, 1957, 1973 Gr. Brit. TS No. 1, pt. II (Cmd. 5179 II), 298 UNTS 11.

FN175 IWC/35th Mtg./1983, at 23. 
FN176 Martin \& Brennan, Enforcing the International Convention for the Regulation of Whaling: The Pelly and Packwood-Magnuson Amendments, 17 DEN. J. InT'L L. \& POL'Y 293, 300-03 (1989).

FN177 ECO, No. 1, July 18, 1983, at 4-5; 2 P. BIRNIE, supra note 40, at 626-27. A U.S. boycott of Norwegian fishing products was expected to be catastrophic for the Norwegian economy since Norway was dependent upon such exports. Japan was already limited under the PackwoodMagnuson Amendment to catching no more than 100,000 tons of fish in U.S. coastal waters.

FN178 4 CITES, PRoC. 1063-69, 1118 (1986); 2 P. BIRNIE, supra note 40, at 577.

FN179 CITES in 1983 had an impressive membership of 90 signatory states and 76 that had ratified the Convention. The latter figure is even higher now. 2 P. BIRNIE, supra note 40, at 577.

FN180 IWC/36th Mtg./1984/OS (Brazil).

FN181 Id. (Japan).

FN182 Id. (the Republic of Korea).

FN183 Id. (the USSR). On the whole, there were no significant developments at the IWC's 1984 meeting beyond those relating to the 1982 moratorium. Of the countries that supported the moratorium, many cited their national laws and policies in support of the conservation measures.

FN184 IWC/37th Mtg./1985/OS (Japan).

FN185 Id. (the Philippines).

FN186 Id. (the USSR).

FN187 Id. (India).

FN188 IWC/38th Mtg./1986/OS (Brazil).

FN189 Id. (Japan).

FN190 Id. (Oman).

At the 39th meeting, in 1987, Japan continued to protest the moratorium but officially continued to adhere to it. IWC/39th Mtg./1987/OS (Japan). South Korea and Brazil also reported complying with the moratorium, despite attendant economic hardships. Id. (South Korea and Brazil).

FN191 ASIL, International Environmental Law Interest Group Newsletter, Oct. 1990, at 5-6.

FN192 However, Japan and Iceland continue to exploit a large loophole in the name of "scientific research." For example, in 1987 Japan submitted a scientific research program to the IWC Scientific Committee stating that approximately 825 minke whales and 50 sperm whales would be lethally taken. IWC/39th Mtg./1987, at 48-53. Iceland's 1987 research program involved the hunting and killing of 80 fin and 20 sei whales. IWC/40th Mtg./1988, Report of the Scientific Committee, para. 4. Inasmuch as even a single whale, by its sheer size, would overwhelm any modern scientific research laboratory, providing enough material to keep a team of scientists busy for months, the label "scientific research" must be critically examined in light of such claims. It is estimated that some 600 great whales will have been slaughtered in 1990 under various "scientific research" programs. 
FN193 See International whaling ban upheld; dolphins may get protection, Chicago Trib., July 8, 1990, § 1, at 9, cols. 1-5; GA Res. 44/225 (Dec. 22, 1989). Drift-net fishing has been widely condemned for indiscriminately killing small cetaceans that swim into the nets.

FN194 UNEP was itself a direct consequence of the Stockholm Conference of 1972.

FN195 IUCN-UNEP-WWF, World Conservation Strategy, Item 18.5 (1980).

FN196 See Kennedy, Form and Substance in Private Law Adjudication, 89 HARV. L. REV. 1685, 1713-22 (1976).

FN197 See Balkin, The Rhetoric of Responsibility, 76 VA. L. REV. 197, 206-12 (1990).

FN198 Cf. Professor Christopher Stone's call for "moral pluralism" with respect to animals and the environment. C. Stone, Earth And Other Ethics: The Case For Moral Pluralism (1987). Moral pluralism in Professor Stone's sense would clearly be a fruition of the more generalized concept of broadening international cultural consciousness. However, Professor Stone would not want to extend rights to whales; he says it "seems more appropriate to fabricate our relations with them out of our duties rather than out of their rights." Id. at 219.

FN199 Although the opinio juris component of international custom is psychological, it is evidenced by completely objective materials: the articulations of rules by states. See A. D'AmATO, supra note 15, at 74-87. For a brief description of the customary law process in terms of the clash between thesis (assertion of an entitlement) and antithesis (violation), see A. D'AMATO, INTERNATIONAL LAW: PROCESS AND PROSPECT 97-98 (1987).

FN200 C. Stone, Should Trees Have Standing? Towards Legal Rights For Natural ОBJECTS (1974).

FN201 For specific examples and citations, see id. at 3-5.

FN202 For specific examples and citations, see id. at 5-6.

FN203 See Developments in the Law - Corporate Crime: Regulating Corporate Behavior Through Criminal Sanctions, 92 HARV. L. REV. 1227 (1979).

FN204 This is not an example given by Professor Stone.

FN205 One could imagine a highly formalistic court taking such an approach, but even then, only if impelled to do so because of some other extrinsic equitable factor such as the unconscionableness of the contract.

FN206 C. STONE, supra note 200, at 41.

FN207 Professor Stone does not argue in these natural-law terms. He makes a comparable argument on the basis of the "force" of "ordinary language." Id.

FN208 Id.

FN209 478 U.S. 221 (1986).

FN210 Id. at 230 n.4.

FN211 The decision has been widely criticized. See, e.g., Whitney \& Perles, Critical Issues Left Unresolved in Japan Whaling Association v. American Cetacean Society: The Relationship of the Administrative Procedure Act to the Pelly and Packwood Amendments, 28 VA. J. INT'L L. 679 
(1988); Gibson, Narrow Grounds for a Complex Decision: The Supreme Court's Review of an Agency's Statutory Construction in Japan Whaling Association v. American Cetacean Society, 14 Ecology L.Q. 509 (1987); Wilkinson, The Use of Domestic Measures to Enforce International Whaling Agreements: A Critical Perspective, 17 DEN. J. INT'L L. \& POL'Y 271 (1989).

FN212 The immediate effect of Japan Whaling Ass' $n$ v. American Cetacean Soc'y was to permit Japan to kill 1,200 sperm whales — a species that is "widely believed" to be "under the threat of extinction." Note, Japan Whaling Association v. American Cetacean Society, 6 WIS. INT'L L.J. 129, 150 (1987). While it might be difficult for the American Cetacean Society or Greenpeace to prove that the removal of 1,200 sperm whales from the oceans of the world would actually result in a diminution of their members' ability to watch and study whales - given the difficulty of finding and studying even one whale not in captivity - the contrasting enormity of the loss to the sperm whale species of 1,200 of their number suggests that perhaps the Justices were not sufficiently empathetic to the asserted "injury in fact" of the environmental organizations.

FN213 See D'Amato, The Moral Dilemma of Positivism, 20 VAL. U.L. REV. 43 (1985).

FN214 H.L.A. HART, THE CONCEPT OF LAW 199-200 (1961).

FN215 For discussion and references, see D'Amato, Lon Fuller and Substantive Natural Law, 26 AM. J. JURIS. 202 (1981).

FN216 "Law" cannot be an objective "fact" only because people are asked to respect it and judges are asked to enforce it. Thus, "law" has an inherent normativeness. For a general discussion, see A. D'AMATO, supra note 38, at 221-27. For an account of the normative dimension of law affecting the content of international law through the imperative of international justice, see D'Amato \& Engel, State Responsibility for the Exportation of Nuclear Power Technology, 74 VA. L. REV. 1011, 1042-49 (1988).

FN217 Calabresi \& Melamed, Property Rules, Liability Rules, and Inalienability: One View of the Cathedral, 85 HARV. L. REV. 1089 (1972).

FN218 Id. at 1090.

FN219 Id. at 1111-15.

FN220 Falk, supra note 10, at 251.

FN221 Sumi, supra note 136.

FN222 Id. at 322.

FN223 Id. at 338-39.

FN224 Id. at 339-40.

FN225 Id. at 339.

FN226 Id. at 321.

FN227 In 1987 the Chairman of the IWC reported Japan's position on this point to be that "the only way to reduce uncertainty in knowledge of the stocks is by carrying out research." IWC/39th Mtg./1987, Chairman's Report, para. 8.2(c).

FN228 Sumi, supra note 136, at 327. 
FN229 Id. at 340.

FN230 Id. at 321.

FN231 Nor are we informed whether any of the executives of the dissolved Nippon Kyodou Hogei Co. found new employment in the Institute of Cetacean Research or, if they did, whether they retained or even increased their former salaries.

FN232 To his credit, Professor Sumi quotes Dr. Roger Payne, representative of Antigua and Barbuda in the IWC: "There is nothing scientific about killing 875 whales and selling the meat. It's just a scam, cloaked, unfortunately, in pseudo-science." Sumi, supra note 136, at 360 (quoting World Wildlife Fund, Press Release (Sept. 1, 1987)). Professor Sumi immediately follows this quotation with the observation that "it is truly regrettable that the WWF, with a worldwide reputation, has been influenced by the narrow-minded and prejudiced view of a radical protectionist." Id.

FN233 Id. at 327.

FN234 Id. at 336. The IWC's Technical Committee specified, among other things, that any permits for killing whales for scientific research should specify the number, sex, size and stock of the animals to be taken, "opportunities for participation in the research by scientists of other nations," and "possible effect on conservation of the stock." IWC/31st Mtg./1979, Chairman's Report, para. 7.

FN235 Professor Sumi does not claim that international law is nonexistent; to the contrary, he invokes international legal reasoning in support of the Japanese position on whaling.

FN236 Sumi, supra note 136, at 363.

FN237 For a similar analysis with respect to the lawmaking impact of the United Nations Charter, see D'Amato, Trashing Customary International Law, 81 AJIL 101 (1987).

FN238 Sumi, supra note 136, at 318.

FN239 Id.

FN240 "We rarely stop to consider that the animal that kills with the least reason to do so is the human animal," observes Professor Singer. "We think of lions and wolves as savage because they kill; but they must kill, or starve. Humans kill other animals for sport, to satisfy their curiosity, to beautify their bodies, and to please their palates." P. Singer, ANimAl LiBERATION: A NEW ETHICS FOR OUR TREATMENT OF ANIMALS 235 (1975).

FN241 Compare this remark of H. S. Salt: "[S]poken with friendly earnestness, [the question] was this: 'Don't you think that animals were sent us as food?' I have since heard the same pathetic question asked many scores of times. What can one say in reply to it except that the invoice has not yet been received?" H. S. SALT, SEVENTY YeArS AMONG SAVAGES (1921), quoted by S. Godlovitch, Utilities, in Animals, Men And Morals 173, 173 (S. Godlovitch, R. Godlovitch \& Harris eds. 1971).

FN242 See the special issue, Bowhead Whale: Whaling and Biological Research, 42 MARINE FISHERIES REV. 1 (1980).

FN243 Doubleday, supra note 172.

FN244 Dec. 16, 1966, 999 UNTS 171. 
FN245 See M'Gonigle, The "Economizing" of Ecology: Why Big, Rare Whales Still Die, 9 ECOLOGY L.Q. 142 (1980).

FN246 Doubleday, supra note 172, at 385.

FN247 Id. at 390.

FN248 Id. at 391.

FN249 Id. at 393.

FN250 C. STONE, supra note 198, at 220.

FN251 Doubleday, supra note 172, at 392.

FN252 For a discussion of this legal-historical progression, see A. D'AMATO, supra note 199, at 194-204, 215-22.

FN253 Doubleday, supra note 172, at 392.

FN254 The Inuit have not "farmed" the whales either. As regards a chicken farm, for instance, the argument can be made that, but for the raising and nurturing of the chickens on the farm, they would never have come into existence; therefore, there is perhaps some justification for using them as human food. To be sure, animal rightists would disagree with such a justification. See, e.g., T. Regan, The CAse For Animal Rights 347-49 (1983). But in any event, a similar justification would not apply to indigenous people who hunt and kill wild animals such as whales.

FN255 Cf. The marauding armies of the fourteenth century described by B. TUCHMAN, A DISTANT MirRoR: THE CALAMITOUS FOURTEENTH CENTURY (1978).

FN256 Another way of looking at this matter is to say that entitlements, by their nature, cannot be intertemporal rights. Cf. D'Amato, International Law, Intertemporal Problems, in [Installment] 9 ENCYCLOPEDIA OF INTERNATIONAL LAW 191 (R. Bernhardt ed. 1986).

FN257 Obviously, as stated, this proposal could lead to a form of social blackmail. To implement it fairly, one would have to take into account not the continued threat to allow hunters to hunt wild animals, but rather the discounted expectation of how long the animals would remain in existence to be hunted given their exploitation at the hands of hunters. The latter is a much more manageable price to pay, and is purely compensatory.

FN258 See L. FUlleR, THE LAW IN QUeST OF ITSELF (1940).

FN259 Professor Franck has recently written an extended account of the normativity that comes from social expectation of a pattern of evenhanded authority and control. See T. FRANCK, supra note 38.

FN260 For a discussion in the law of the sea context of the customary-law transformation of the implicit into the explicit, see D'Amato, How Does Customary International Law Develop?, in CoNSENSus And Confrontation: The United States AND the Law Of The SEA Convention 170 (J. M. Van Dyke ed. 1985). 